\title{
Õpetajakoolituse üliõpilaste hoiakud ja teadlikkus soolise võrdõiguslikkuse küsimuses
}

\author{
Eve Mägi ${ }^{a 1}$, Helen Biin ${ }^{\text {ab }}$, Karmen Trasbergc ${ }^{c}$ Kersti Kruus ${ }^{d}$ \\ a Poliitikauuringute Keskus Praxis \\ b Tartu Ülikooli ühiskonnateaduste instituut \\ c Tartu Ülikooli haridusteaduste instituut \\ d Eesti Kaitseliit
}

\begin{abstract}
Annotatsioon
Soolise võrdõiguslikkuse taotlemisel lähtutakse põhimõttest, et naistel ja meestel on võrdsed õigused, kohustused, võimalused ja vastutus nii hariduse omandamisel kui ka tööelus. Kuna haridusel, sh õpetajakoolitusel, on väärtuste ja hoiakute kujundamisel oluline roll, käsitletakse seda sageli soolise võrdõiguslikkuse edendamise ühe võtmevaldkonnana. Uurimuse eesmärk on kirjeldada Eesti õpetajakoolituse ja kasvatusteaduste valdkonna üliõpilaste hoiakuid ja teadlikkust soolise võrdõiguslikkuse küsimuses, sh osutada nende erinevustele üliõpilaste üldkogumist. Selleks kombineeriti kvantitatiivset ja kvalitatiivset uurimisviisi. Uuringus küsitleti üliõpilasi $(N=2748)$ soolise võrdõiguslikkusega seotud hoiakute ja kogemuste teemal ning intervjueeriti õpetajakoolituse üliõpilasi $(N=20)$ fookusrühmades, et mõtestada kõrgkoolide õpetamispraktikat ning seda mõjutavaid väärtusi ja norme soolise võrdõiguslikkuse vaatenurgast. Ilmnes, et üliõpilased suhtuvad soolisesse võrdõiguslikkusse soosivalt ja tajuvad ebavõrdset kohtlemist soo alusel probleemina. See on hea potentsiaal, mille varal arendada tulevaste õpetajate valmisolekut sootundlikuks pedagoogikaks. Selgelt eristusid ka nende üliõpilaste rühmad, kelle hoiakutes väljenduvad teiste rühmadega võrreldes enam soolised stereotüübid (algajad üliõpilased ja mehed). Uurimuse tulemused täiendavad varasemate uurimuste omi, milles käsitletakse sugupoolte aspekti arvestamist hariduses, ning neil on praktiline väärtus õpetajakoolituse õppekavade kujundamisel.
\end{abstract}

Võtmesõnad: sooline võrdõiguslikkus, soolõime õpetajakoolituses, hoiakud, sooteadlikkus, õpetamine kõrgkoolis

1 Poliitikauuringute Keskus Praxis, Tornimäe 5, 10145 Tallinn; eve.magi@praxis.ee 


\section{Sissejuhatus}

Sooline võrdõiguslikkus on demokraatliku ühiskonna üks alustalasid ja eesmärke. Kõigi ühiskonnaliikmete, nii meeste kui ka naiste võimalused oma potentsiaali maksimaalselt realiseerida on ühtaegu inimõigus ning sotsiaalse ja majandusliku kestliku arengu eeldus. Kuigi Eestit tõstetakse sageli postsotsialistlike riikide hulgas esile kui majandus- ja sotsiaalarengu edulugu, on mitmed soolise võrdõiguslikkuse näitajad meil negatiivses mõttes esirinnas. Poiste ja tüdrukute erinev edukus koolis, poiste suurem väljalangevus, erialavalikute soopõhisus, naiste madalam palk meestega võrreldes, tööturu segregeeritus ning meeste oluliselt lühem eluiga ja kehvem tervis on vaid mõned näited selle kohta, et naiste ja meeste võrdsetest võimalustest me veel rääkida ei saa (Anspal, Kraut, \& Rõõm, 2010; European Institute of Gender Equality, 2015; Papp, 2012a, 2012b; Roosalu, 2014; Vainu, Järviste, \& Biin, 2010).

Kasvatusel ja õpetusel on ühiskonnaliikmete väärtuste ja hoiakute kujundamisel täita oluline osa. Juba kodust algav sooliste hoiakute kujundamine jätkub koolis ning stereotüüpne lähenemine soorollidele võib viia soolise ebavõrdsuse püsimiseni ka hilisemas töö- ja pereelus (Ekström, 2010; Hynninen \& Juutilainen, 2006; Papp, 2013). Kuna kool ei toimi vaakumis, mõjutavad sealset tegevust ja õpetuse sisu ühiskonnas levinud hoiakud ja väärtused, kuid koolis toimub ühtlasi nendesamade hoiakute ja väärtuste kujundamine. Seetõttu on tähtis, et koolikultuur, õppekavad ja õpetajad käsitleksid soolist võrdõiguslikkust olulise printsiibina ega taastoodaks soolisi stereotüüpe.

Siinses uurimuses käsitletakse Eesti õpetajakoolituse üliõpilaste hoiakuid ja teadlikkust soolise võrdõiguslikkuse küsimuses. Kuna õpetajatel on võimalik murda soost tingitud stereotüüpe, on erakordselt oluline analüüsida, kuidas tajuvad soolist võrdõiguslikkust õpetajaks õppijad. Järgnevalt tutvustatakse teoreetilist raamistikku, mis aitab avada soolise võrdõiguslikkuse taotlusi nii ühiskonna kui ka kooli tasandil ning õpetajakoolituse võimalikku potentsiaali ja panust.

\section{Soolise võrdõiguslikkuse mõiste}

Sooline võrdõiguslikkus on Eesti avalikus diskursuses palju kasutatud, kuid harva lahti seletatud mõiste. Soolist võrdõiguslikkust võib defineerida mitmeti. Sooline võrdõiguslikkus on inimõigus ja avalik hüve, mis on demokraatia ja majanduse arengu eeldus (Marling, 2011, lk 288). Sageli toetutakse mõiste defineerimisel soolise võrdõiguslikkuse seadusele 
(SoVS), mille kohaselt on sooline võrdõiguslikkus „naiste ja meeste võrdsed õigused, kohustused, võimalused ja vastutus tööelus, hariduse omandamisel ning teistes ühiskonnaelu valdkondades osalemisel” (SoVS $\$ 3 \lg 1$ ). Seega peavad soolise võrdõiguslikkuse põhimõtte kohaselt naistel ja meestel olema eri eluvaldkondades võrdsed õigused ja võimalused, inimese sugu ei tohi piirata võimalusi oma elu kujundada ning naiste ja meeste soove, vajadusi ja pürgimusi peab väärtustama võrdselt (Pehk, 2014). Soolise võrdõiguslikkuse printsiip ei tähenda, et naised ja mehed peavad muutuma ühesuguseks. Küll aga peitub selle põhimõtte taga idee, et inimeste valikud ja võimalused elus ei tohi sõltuda pelgalt naise või mehena sündimise asjaolust. Kuigi ülaltoodule lisaks võib soolist võrdõiguslikkust käsitleda ka poliitikavaldkonnana, mis tasakaalustab naiste ja meeste sotsiaalseid suhteid, või ühiskonna arengu eesmärgina (Marling, 2011, lk 288), käsitletakse selles artiklis soolist võrdõiguslikkust kui naiste ja meeste võrdseid õigusi ja võimalusi ning nende pürgimuste ja vajaduste võrdset väärtustamist.

Eestis kannab võrdsete võimaluste, sh soolise võrdõiguslikkuse teema Nõukogude Liidu avaliku propagandaga seostudes tugevat negatiivset ajaloolist pitserit. Taasiseseisvunud Eestis kerkis soolise võrdõiguslikkuse teema teravamalt esile seoses Euroopa Liidu liitumisprotsessiga, mille üheks eelduseks oli muu hulgas soolist võrdõiguslikkust ja võrdseid võimalusi puudutavate õigusnormide kehtestamine. Kuigi soolise võrdõiguslikkuse seadus võeti vastu juba üle kümne aasta tagasi ning soolise võrdõiguslikkuse mõiste pole enam päris tundmatu, on muutused hoiakutes ja käitumises visad tulema ning valdkond seostub paljude jaoks endiselt ebaõnnestunud sotsialistliku emantsipeerimisprojekti või Euroopa Liidust imporditud ja meile sobimatu kontseptsiooniga. Toetus võrdsete võimaluste põhimõttele kui ideaalile kasvab aasta-aastalt, kuid arvestatav osa elanikkonnast toetab peresiseses tööjaotuses, laste kasvatamisel ja ka tööturukäitumisel endiselt traditsioonilisi, soostereotüüpidest lähtuvaid soorolle ja hoiakuid (Roosalu, Kall, \& Aavik, 2014; Vainu et al., 2010), inimeste teadlikkus valdkonnast on pigem väike (Vainu et al., 2010). Soolise võrdõiguslikkuse põhimõtte lõimimine organisatsioonide igapäevapraktikasse, riiklikesse strateegiatesse, arengukavadesse ja seadustesse on alles lapsekingades (vt nt Pajumets et al., 2013). Kuigi viimastel aastatel on kolmanda sektori organisatsioonid ja kodanikuliikumine märgatavalt aktiveerunud ning Euroopa Liidu ja Norra riigi toel on algatatud mitmeid olulisi projekte, võib endiselt öelda, et Eesti ühiskonnas on usk sellese, et soolise võrdõiguslikkuse edendamine on vajalik ühiskonna majandusliku ja sotsiaalse arengu tagamiseks ning selle puudumine takistab ühiskonnaliikmete võimete ja annete tõhusat rakendamist, veel õhuke (Mackevičiùtè, 2008; Pehk, 2014). 
Kuigi sooline võrdõiguslikkus on printsiibina sisse kirjutatud nii Euroopa Liidu kui ka Eesti õigusaktidesse, ei taga seadusega garanteeritud ühesugused õigused veel ühiskonda, mille kõigil liikmetel on võrdsed võimalused eneseteostuseks. Naiste ja meeste võrdsed võimalused ei puuduta pelgalt õigusi ja kohustusi, vaid saavad teoks üksnes juhul, kui mõlema soo jaoks on ka tegelikkuses tagatud ligipääs ühesugustele tingimustele ja võimalustele ning nad saavad seadusega tagatud õigusi reaalselt kasutada (Mackevičiūtè, 2008). Üksnes õigusaktidele toetumine soolise võrdõiguslikkuse poole pürgimisel on problemaatiline, kuna seadusega on võimalik reguleerida vaid õigusi, kohustusi ja vastutust, seadused ei kohaldu kõigile eluvaldkondadele (nt eraelu) ning seadusesätetel võivad olla naistele ja meestele erinevad tagajärjed (ibid.).

Kuna sooline võrdõiguslikkus ei ole ühiskonna arenguga iseeneslikult kaasnev nähtus, vaid nõuab sihikindlat tööd (Kütt \& Papp, 2012; Mackevičiūtè, 2008), võib ja tuleb seda käsitleda valdkondadeülese poliitilise eesmärgina (Mackevičiūtè, 2008; Võrdõigusvoliniku ..., 2015). Oluline on rõhutada, et soolise võrdõiguslikkuse poliitikas tuleb arvestada poiste ja tüdrukute, naiste ja meeste erinevaid elustiile, huvisid ja vajaduste eripärasid, st soolise võrdõiguslikkuse poole pürgimine ei tähenda soovi saavutada sooneutraalsust ehk sugude kaotamist (Mackevičiūtè, 2008). Soolise võrdõiguslikkuse vastandiks on sooline ebavõrdsus ehk inimese soo alusel erinevate võimaluste pakkumine ja erinev kohtlemine, mitte sooline erinevus ehk kahe bioloogiliselt erineva soo olemasolu (Pehk, 2014).

\section{Sooline võrdõiguslikkus Eestis}

Soolise võrdõiguslikkuse indeksid ${ }^{2}$, riiklik soopõhine statistika ja uuringud kinnitavad, et Eesti ühiskond on soolise võrdõiguslikkuse saavutamisest veel kaugel. Erinevad ootused ja võimalused saadavad naisi ja mehi läbi kogu elutee. Juba lapsepõlves hakkame poisse ja tüdrukuid kasvatama eri maailmas ja eri maailma jaoks, andes neile eluks kaasa erinevad oskused. Nii õpetame mõlemast soost lastele rahaga ümberkäimise oskust, kuid poegadele soovime sellele lisaks õpetada ettevõtlikkust, autojuhtimist ja tehnika käsitsemist, samas kui tütardele õpetame söögitegemist, viisakust, käitumis- ja eneseväljendusoskust (Aavik \& Uusma, 2014).

2 Vt nt Euroopa soolise võrdõiguslikkuse indeks (http://eige.europa.eu/gender-statistics/gender-equality-index) või maailma majandusfoorumi soolõhede raport (http://www.weforum.org/reports/global-gender-gap-report-2015). 
Kodus alguse saanud erinevused kohtlemises, ootustes ja toimetulekus ilmnevad ka haridusasutustes. Kuigi Eestis on ligipääs üldharidusele võrdselt tagatud nii poistele kui ka tüdrukutele, on haridussüsteem üheks teravaks ebavõrdsuse ilmnemise kohaks. Euroopa Liidu riikidest on Eesti hariduselu kõige enam sooliselt jaotunud (European Institute of Gender Equality, 2015; Vainu et al., 2010). Poiste ja tüdrukute erinev kohtlemine lasteaedades (Aavik \& Kajak, 2009), poiste kehvemad õppetulemused ja suur väljalangevus põhikoolist, erialavalikute sügav sooline segregeeritus ja kõrgema haridusega naiste märgatavalt suurem osakaal tööealise elanikkonna seas (Papp, 2012a, 2012b) on vaid mõned ilmekad näited Eesti haridussfääri soolise kallutatuse ja ebavõrdsete võimaluste kohta.

Erinevad valikud ja võimalused kanduvad koolist edasi tööturule. Kuigi Eesti naiste tööhõive määr on kõrge, valitseb meil Euroopa suurim sooline palgalõhe (Eurostati andmetel oli 2015. aastal palgalõhe Eestis 29,9\%, samal ajal kui Euroopa Liidu keskmine sooline palgalõhe on 16,2\%, Vt Eurostat, 2015), samuti on Eestis Euroopa Liidu üks enim sooliselt segregeerunud tööturge. Olukord on seda märkimisväärsem, et Eesti naised on võrreldes meestega oluliselt kõrgemalt haritud. Seega ei ole naiste potentsiaali tööturul piisaval määral ära kasutatud, naiste eneseteostus on piiratud ning riigi pakutav haridus toob ühiskonnale vaid osa võimalikust tulust ja arengust. Erinevad valikud tööelus, sissetulekute ebavõrdsus ning laste ja teiste pereliikmete eest hoolitsemisega seotud karjäärikatkestuste pikkus viivad tulevikus ebavõrdsuseni pensionites. Teisalt on Eesti mehed märkimisväärselt halvema tervise, suurema riskikäitumise ja lühema elueaga kui Eesti naised (EIGE, 2015).

Seega võib öelda, et kuigi Eesti on seadusandlikul tasandil kehtestanud nõuded soolise võrdõiguslikkuse toetamiseks ja ebavõrdse kohtlemise keelustamiseks ning liitunud mitmete rahvusvaheliste konventsioonide ja lepetega, pole de jure võrdõiguslikkus ootuspäraselt kaasa toonud naiste ja meeste võimaluste, õiguste ja kohustuste võrdsemat jagunemist. Võrdsemate võimaluste saavutamist mõjutavad peale seadusandliku raami ja riikliku poliitika olulisel määral ka kultuur ehk väärtused, hoiakud ja uskumused, mis puudutavad naiseks ja meheks olemist (Inglehart \& Norris, 2003).

Kuigi enamik Eesti inimesi tajub meeste positsiooni ühiskonnas naiste omast paremana (Tiidenberg, 2014; Vainu et al., 2010), ei pea Eesti elanikud soolist ebavõrdsust oluliseks probleemiks - ligi 2/3 Euroopa Liidu elanikest leiab, et nende riigis on sooline ebavõrdsus väga levinud või levinud, kuid Eestis on samal seisukohal vaid $42 \%$ elanikkonnast (Eurobaromeeter, 2010) ning üle 1/3 inimestest usub, et Eestis on naised ja mehed võrdsed (Vainu 
et al., 2010). Kui võrrelda neid arve Eesti tulemustega ülalviidatud soolise võrdõiguslikkuse indeksi eri valdkondades, ilmneb suur lõhe tegeliku olukorra ja probleemi tajumise vahel. Oskust soolist kihistumist märgata, analüüsida ning probleemiks pidada pärsivad ühiskonnas levinud soostereotüübid ja eelarvamused. Seda mõjutavad ka inimeste vähene teadlikkus võrdse kohtlemise olulisusest, eelarvamused ning napid oskused ebavõrdset kohtlemist märgata ja sellele reageerida (Pajumets et al., 2013).

\section{Hariduse roll soolise ebavõrdsuse vähendamisel}

Haridus laiemalt ja kool kui institutsioon kitsamalt avaldavad soolise võrdõiguslikkuse edendamisele suurt mõju (Promoting gender mainstreaming ..., 2004). Ühest küljest on oluline, et võimalus hariduse omandamiseks oleks tagatud nii poistele kui ka tüdrukutele. See võib tähendada ligipääsu haridusele (nt õigus ja võimalus koolis käia), aga ka seda, et õppekavad, õppemeetodid ja õpetamispraktika toetavad mõlemast soost laste ja noorte püsimist koolis ja hariduse omandamist. Kui poisse ja tüdrukuid koheldakse koolis erinevalt, viib see erinevusteni õppeedukuses, koolikeskkonna tajumises, erialavalikutes (Ekström, 2010) ja õpilaste tulevikuvõimalustes. Teisest küljest on koolil kui kesksel sotsialiseerijal täita tähtis roll ühiskonna väärtuste ja normide looja ning edasikandjana. Koolis kujundatud väärtused ja hoiakud kanduvad edasi tööturule ja teistesse ühiskonnaelu valdkondadesse. Seeläbi mõjutab koolis toimuv võrdõiguslikkust ka muudes eluvaldkondades. Samal ajal lähtuvad haridustöötajate väärtushinnangud, hoiakud ja tavad (nt õpetamisviisid, õppekavade ja -materjalide loomine) ühiskonnas laiemalt levinud normidest, väärtustest ja hoiakutest (Schalkwyk, Thomas, \& Woroniuk, 1997).

Kuna kool ja haridus on tugevalt seotud inimese identiteedi kujunemise ja kujundamisega, on soolise võrdõiguslikkuse edendamisel oluline roll õpetajal. Õpetamise ja juhendamise abil on võimalik kahtluse alla seada meeste ja naiste ning soolise võrdõiguslikkusega seotud hoiakuid ja stereotüüpe. Selline küsimärgistamine võimaldab mõjutada noorte inimeste arusaama meheks või naiseks olemisega kaasnevatest piirangutest ja võimalustest (Hynninen \& Juutilainen, 2006) ning suunata noorte eluvalikuid stereotüüpsetest rolliootustest mööda. Erialavalikute, väärtuste ja soorollide muutmise kaudu saab aga omakorda mõjutada ametialade segregeeritust, soolist palgalõhet, ühiskonnaliikmete eneseteostuse võimalusi ja soolist ebavõrdsust ühiskonnas laiemalt. Kuigi haridussektori reformimine üksinda ei ole soolise ebavõrdsuse kaotamiseks piisav, sest 
eluvaldkondi läbiva probleemina tuleb sellega tegelda mitmel tasandil ja eri valdkondades, on sellel väga suur potentsiaal mõjutada meeste ja naiste võrdseid võimalusi ning soolise võrdõiguslikkuse kui põhiväärtuse aktsepteerimist (Schalkwyk et al., 1997).

Soolise võrdõiguslikkuse põhimõtete väärtustamine ja edendamine koolis eeldavad sootemaatika lõimimist õppekavadesse ning õpetamisja käitumispraktika muutumist. Teadvustamata soolised stereotüübid ja eelarvamused suunavad õpetaja tegevust, mõjutades õppekavade sisu, õppematerjale, koolikultuuri, õpilaste hindamist jmt (Kütt \& Papp, 2012). Seetõttu peavad õpetajad teadvustama ja oskama märgata neid internaliseeritud käitumismalle ja hoiakuid, mida nad töö käigus õpilastele edasi annavad. Õpetajaid ettevalmistavad kõrgkoolid saavad seda protsessi toetada, andes tulevastele õpetajatele vajalikke teadmisi ja oskusi (Cushman, 2012).

Õpetaja väärtustel, nii isiklikel kui ka õpetamist puudutavatel, on koolielus oluline roll, mistõttu tuleb väärtuste adresseerimisele õpetajahariduses pöörata suurt tähelepanu (Fraser \& Saunders, 1998, viidatud Chong \& Cheah, 2009 järgi). Õpetamise efektiivsuse seisukohast on osa väärtustest alusväärtused, sh ka uskumus, et kõik õpilased on võimelised õppima, soov toetada õpilasi eri moel, et nende potentsiaali realiseerida, ning kõigile õpilastele võrdväärse haridusliku toe pakkumine, sõltumata nende soost, rahvusest, võimetest või sotsiaalmajanduslikust kuuluvusest (Chong \& Cheah, 2009). Teisisõnu on õpilaste erinevuste, sh sooliste erinevuste märkamine ja väärtustamine õpetajatöös kriitilise tähtsusega. Sootemaatika lõimimine õpetajakoolitusse on äärmiselt oluline, kuna õpetaja roll väärtuste ja hoiakute edasiandjana on tänu otsesele ja tihedale kontaktile õpilastega väga suur. Ka sõltub viis, kuidas soolise võrdõiguslikkuse teema lõimitakse eri õppeainetesse, eelkõige just õpetajast. Tulevastele õpetajatele peab pakkuma nii teoreetilisi teadmisi soolisest võrdõiguslikkusest ja soo rollist koolis, praktilisi oskusi märgata soolisi stereotüüpe ja mittesootundlikku või diskrimineerivat käitumist kui ka pedagoogilisi oskusi selliste olukordade lahendamiseks (Bondestam, 2010; Hynninen \& Juutilainen, 2006).

Zittleman ja Sadker (2002) tõdevad, et soolisusega seotud probleemid ei saa õpetajakoolituses piisaval määral tähelepanu. Leitakse, et soolise võrdõiguslikkuse temaatikat peljatakse õpetajakoolituses käsitleda, kuna teema lahkamine tekitab palju emotsioone, kuid nõuab samal ajal teaduspõhist lähenemisviisi (ibid.). Soolise võrdõiguslikkuse teema on nii keeruline ja ebamugav, et mitmed Põhja- ja Lääne-Euroopa ülikoolid jätavad sootemaatika kõrvale, suunates põhitähelepanu teistele mitmekesisuse 
aspektidele (Sanders, 2002). Õpetajakoolituse suhtes on kriitiline ka Skelton (2007), väites, et tihti nimetatakse soolise võrdõiguslikkuse valdkonda läbivaks teemaks õpetajakoolituse õppekavades, kuid tegelikkuses on see „eufemism mitte midagi tegemisele” (lk 678). Fookuse puudumise tõttu väljuvad ülikoolidest noored õpetajad, kelle mõttemaailm on stereotüüpne (Butler, 2006; Weaver-Hightower, 2003; Younger \& Warrington, 2008).

Ka Eesti õpetajahariduses on sooteema seni tagaplaanile jäänud haridusvaldkonda reguleerivad dokumendid ei kajasta sooteadliku lähenemisviisi pädevust (Sugu ja soolisus ..., 2015). Põhikooli ja gümnaasiumi riiklikud õppekavad viitavad küll soolisele võrdõiguslikkusele kui koolielu korraldamise ühele põhimõttele (Kütt \& Papp, 2012), kuid see ei rakendu tegelikus koolielus. Uuringute põhjal võib väita, et väga paljude õpetajate ja koolijuhtide ootused ja hoiakud ning õppekavad, õppematerjalid ja variõppekava taastoodavad ja kinnistavad stereotüüpseid soorolle (Papp, 2012a) ega toeta soolise võrdõiguslikkuse põhimõtet. Peale ühiskonnas levinud soonormide ja väärtuste on selle põhjustajaks ka koolijuhtide ja õpetajate puudulik ettevalmistus, kuna soolist võrdõiguslikkust käsitlevaid kursuseid ei pakuta sihtrühmale süstemaatiliselt ülikooliõpingute käigus ega ka hilisema täienduskoolitusvõimalusena.

Siinse uurimuse eesmärk on kirjeldada Eesti õpetajakoolituse ja kasvatusteaduste valdkonna üliõpilaste hoiakuid ja teadlikkust soolise võrdõiguslikkuse küsimuses. Uurimuses otsitakse vastuseid järgmistele uurimisküsimustele.

1. Kuidas üliõpilased tajuvad soolist võrdõiguslikkust ühiskonnas?

2. Missugune on üliõpilaste teadlikkus soolisest võrdõiguslikkusest erialal ja tööturul?

3. Millised on üliõpilaste ootused ja hoiakud soolise võrdõiguslikkuse teema käsitlemiseks erialaõpingute raames?

\section{Metoodika}

Uurimisküsimustele vastamiseks kasutati kvantitatiivse ja kvalitatiivse meetodi kombinatsiooni. Kombineeritud meetodi kasutamine võimaldab sügavamat arusaamist, sh uurimisprobleemi eri nüansside seletamist (Creswell, 2005; Creswell, Plano Clark, Gutmann, \& Hanson, 2003; Ivankova, Creswell, \& Stick, 2006). Kombineeritud meetodi puhul tasakaalustatakse kummagi meetodi nõrki külgi teise meetodi tugevate külgedega, sidudes mõlemad andmestikud usaldusväärsete järelduste tegemiseks (Creswell et al., 2003; Ivankova et al., 2006). Praeguses uuringus 
on kasutatud samaaegset kombineeritud meetodi mudelit. See tähendab, et mõlemad osad on üksteisega seotud ja täiendavad teineteist, võimaldades anda uurimisküsimustele seostatud vastuseid (Creswell, 2005; Creswell et al., 2003; Ivankova et al., 2006).

\section{Valim}

Kombineeritud meetodit kasutades korraldas Poliitikauuringute Keskuse Praxis uuringurühm Eesti kõrgkoolide üliõpilaste seas esindusliku ankeetküsitluse soolise võrdõiguslikkusega seotud hoiakute ja kogemuste kohta ning intervjueeris õpetajakoolituse üliõpilasi fookusrühmades, et mõtestada ülikooli õpetamispraktikat ning seda mõjutavaid väärtusi ja norme soolise võrdõiguslikkuse vaatenurgast.

Ankeetküsitluse üldkogumisse kuulusid kõikide Eesti kõrgkoolide rakenduskõrgharidus-, bakalaureuse- ning magistriüliõpilased. Eesti hariduse infosüsteemi (EHIS) andmetel õppis selliseid üliõpilasi Eesti kõrgkoolides 2014/2015. óppeaasta 10. novembri seisuga kokku 52311.

Sihtrühmani jõudmiseks ja küsitluse toimumise kohta info levitamiseks kasutati mitut teavituskanalit. Kõrgkoolide eripära arvestades sobis selleks elektrooniline teavituskiri koos uuringut tutvustava plakati ja uuringukutsega, mis toimetati koostöös kõrgkoolide infojuhtide ja üliõpilaste esindajatega meililistide, siseveebi ja uudiskirjade kaudu üliõpilasteni. Kommunikatsiooni teises etapis järgnes küsitlusele laiema tausta loomine ja uuringu olulisuse selgitamine väljaspool kõrgkoole. Selleks kasutati mitmesuguseid info- ja suhtluskanaleid, sh Poliitikauuringute Keskuse Praxis uudiskirja, kodulehte, sotsiaalmeediat. Nii tagati sihtrühma teadlikkus küsitluse toimumisest. Arvestades sihtrühmani jõudmiseks kasutatud meetodit ja küsimustikule vastamise vabatahtlikkust, võib eeldada, et küsimustikule vastasid pigem aktiivsemad üliõpilased. Küsitlusele vastajate jaotus õppeastmete alusel on esitatud joonisel 1.

Kokku oli ankeetküsitlusele vastajaid 4525, kasutatavaks osutus 2748 ankeeti. Ülejäänud 1777 ei olnud analüüsiks piisavad järgmistel põhjustel: ankeet oli täidetud poolikult, vastaja esitatud demograafilised andmed olid vastuolulised, vastaja ei kuulunud uuringu sihtrühma (oli gümnaasiumiõpilane), vastaja oli ankeeti täitnud mitu korda (kontaktiks märgitud sama e-posti aadress), vastaja ei täitnud ankeeti korrektselt ehk vastas juhuslikult, kaalumiseks kasutatavatel olulistel tunnustel puudus vastus jne. 


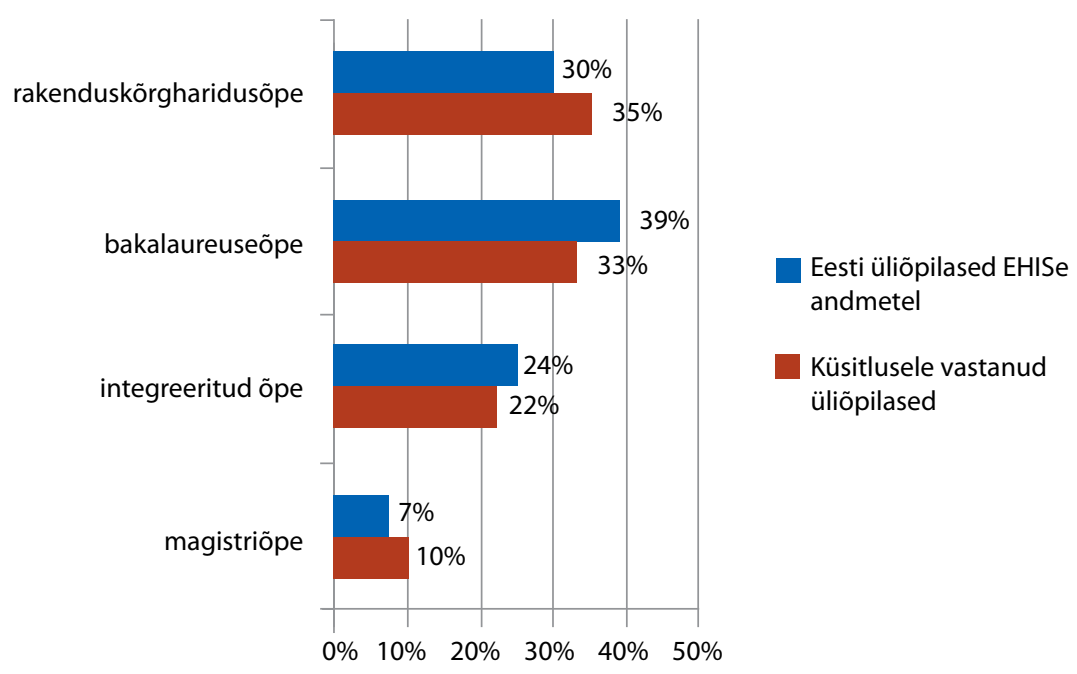

Joonis 1. Küsitlusele vastajate jaotus õppeastmete alusel

Uuringu kvantitatiivse osa valim koosneb seega 2748 üliõpilasest, kes moodustavad 5\% üldkogumist ning kellest 1992 (72\%) on naissoost ja 756 (28\%) meessoost. Vaadates küsitluses osalemise määrasid eri tausttunnuste alusel ja kõrvutades neid EHISe andmetega, selgus, et küsitluses osalesid teistest tunduvalt aktiivsemalt naisüliõpilased (13\% enam kui naisüliõpilaste osakaal üldkogumis). EHISe andmetel oli 2014/2015. õppeaastal üliõpilaskonnas naissoost üliõpilasi 59\% ja meessoost üliõpilasi 41\%. Et saavutada küsitlusandmete parem vastavus uuringu üldkogumile, kaaluti neid soo, vanuse ja õppetaseme alusel. Kaalumise tulemusena korrigeeriti valim üldkogumile vastavaks (valimis alaesindatud rühmadele anti suurem kaal ja üleesindatud rühmadele väiksem kaal, et valim kajastaks võimalikult täpselt üldkogumi struktuuri).

Fookusrühma intervjuud tehti vahemikus september-detsember 2014. Uuringus osales ühe ülikooli 20 õpetajakoolituse üliõpilast, kes jagunesid erialati nelja fookusrühma. Rühmad kujunesid vabatahtlikkuse alusel ja olid sooliselt heterogeensed: osalenutest 12 olid (60\%) naised ja 8 (40\%) mehed. Valimi moodustamisel lähtuti põhimõttest, et uuringusse oleksid kaasatud mitmekülgsete õpikogemustega üliõpilased, et saada võimalikult laiapõhjaline ülevaade arvamustest (Creswell, 2005). Selleks pöörduti õpetajakoolituse bakalaureuseastme (humanitaar-, reaal- ja loodusteaduslikud ained) ning magistriastme mitme aine õpetaja õppekavadel õppivate üliõpilaste poole, kuna nende õpikogemus ei piirdu üldjuhul vaid ühe teaduskonnaga. Samuti on nende koolipraktika mitmekesisem ning neil on vahetum kokkupuude eri teaduskondadest pärit juhendajatega. Valimi moodustamiseks kasutati 
isiklikke kontakte ja üliõpilaste poole pöörduti e-kirjaga. Kõik uuringuga nõustunud üliõpilased kutsuti osalema fookusrühma intervjuus.

\section{Andmete kogumine}

Andmete kogumiseks viidi 2014. aastal läbi ankeetküsitlus Eesti kõrgkoolide üliõpilaste hulgas ning poolstruktureeritud fookusrühma intervjuud õpetajakoolituse üliõpilastega. Ankeedi koostamisel arvestati Eesti elanikkonna seas korraldatava soolise võrdõiguslikkuse monitooringuga, mis võimaldab võrrelda üliõpilaste hoiakuid ülejäänud ühiskonna hoiakutega. Samuti kasutati eeskujudena teiste riikide analoogseid küsitlusuuringuid, nt Lapi ülikooli üliõpilastega tehtud uuringut soolise võrdõiguslikkuse ja võrdse kohtlemisega seotud teadmiste ja kogemuste kohta (Vidén \& Naskali, 2010).

Uuringu valiidsuse tagamiseks katsetati küsitlusankeeti esmalt väikese rühma üliõpilaste seas. Nende tagasiside põhjal täiendati ankeeti: sõnastati ümber küsimusi, lisati vastusevariante ja muudeti teemade järjestust. Küsitlusankeedi lõplik versioon valmis seega teoreetilise raamistiku koostamise, ankeedi katsetamise ja tagasiside kogumise tööetapi põhjal.

Küsitlusankeet (Anniste et al., 2016) koostati eesti keeles, kohaldati veebiküsimustiku jaoks vastavaks ja avaldati veebikeskkonnas Survey Monkey $^{3}$. Veebiküsitluse seire käigus jälgiti üliõpilaste vastamisaktiivsust kõrgkooliti. Vajaduse korral kontakteeruti valimi esinduslikkuse suurendamiseks mõne kõrgkooli infojuhi või kontaktisikuga, kes levitas üliõpilaste hulgas lisainfot küsimustiku kohta.

Kvalitatiivses uuringus kasutati andmekogumiseks fookusrühma intervjuusid. Selline uurimisviis valiti ootusega, et intervjueeritavad täiendavad üksteise teadmisi ning selle põhjal saab nende ühiseid, nagu ka vastuolulisi seisukohti paremini välja selgitada (Laherand, 2008; Milena, Dainora, \& Alin, 2008). Fookusrühma eeliseks (võrreldes individuaalintervjuudega) on see, et eri vaatenurki esindavad osalejad saavad formuleerida oma arvamust võrdluse kaudu, samuti stimuleerivad nad üksteist, sh kiirendavad „teemaga seotu väljaotsimist mälust ning peegeldavad vestlusaluse teema eri aspekte" (Vihalemm, 2014).

Poolstruktureeritud intervjuude kava koostati Praxise uuringurühmas projekti „Soolise võrdõiguslikkuse lõimimine üld- ja kõrgharidusse” (Anniste et al., 2016) raames. Intervjuu kava (Kruus, 2015) koosnes kolmest küsimuste plokist: sissejuhatavad küsimused (intervjuuks häälestamine,

3 https://www.surveymonkey.com. 
võrdõiguslikkuse mõiste määratlemine); osalejate arusaamad soolisest võrdõiguslikkusest; võrdõiguslikkuse teema õpetajakoolituses ja ootused sellele. Intervjueerimisel lähtuti uurija peamistest eetikaaspektidest (vt Eesti teadlaste eetikakoodeks, 2002). Osalemine oli intervjueeritava jaoks vabatahtlik ning teda informeeriti uuringu eesmärkidest. Samuti jälgiti, et intervjuus osalemine ei tekitaks mingil moel uuritavale kahju. Selleks säilitati vastaja konfidentsiaalsus ning saadud informatsiooni kasutati üksnes uurimistöö tarbeks.

\section{Andmete analüüsimine}

Kvantitatiivse andmeanalüüsi esimeses etapis puhastati andmebaas ja kontrolliti vastuseid. Sisestusvigadest tingitud probleemide vältimiseks läbis andmestik veakontrolli ja puhastuse, mille tulemusel eemaldati kokku 1777 vastust.

Andmeanalüüsi meetoditena kasutati peamiselt sagedustabelite analüüsi ( $\chi^{2}$-test) ja keskmiste võrdlust ( $t$-test, dispersioonianalüüs), uuriti nähtustevahelisi seoseid (korrelatsioonianalüüs). Hüpoteeside kontrollimisel kasutati tavalist olulisusnivood 0,05, mis tähendab, et andmete juhuslikkusest põhjustatud kõrvalekaldeid ei esine sagedamini kui ühel juhul 20 otsustusest. Sisukas hüpotees võeti vastu juhul, kui olulisuse tõenäosus $p$ oli väiksem kui olulisusnivoo 0,05 ehk $p<\alpha$ (Philips, 2007). Statistiliselt olulised erinevused rühmade vahel $p<0,05$ juures on tulemuste esitamisel teksti sees märgitud ühe tärniga $\left(^{*}\right)$. Kvantitatiivseks analüüsiks kasutati andmeanalüüsipaketti Stata 12.

Fookusrühma intervjuusid analüüsiti kvalitatiivse induktiivse sisuanalüüsi meetodil, sest see võimaldab keskenduda teksti sisule ning kontekstilisele tähendusele (Laherand, 2008). Induktiivse sisuanalüüsi puhul tuletatakse kategooriad andmetest, mistõttu soovitatakse seda kasutada eelkõige neil juhtudel, mil uuritava teema kohta ei ole piisavalt varasemaid uuringuid või need katavad valdkonda vaid osaliselt (Elo \& Kyngäs, 2008). Praeguses uurimuses lähtuti Elo ja Kyngäse pakutud induktiivse analüüsi etappidest: transkribeeritud tekstide korduv lugemine ning tähenduslike üksuste määramine (lõik intervjuust, mis omas uurimuse eesmärgist olenevalt tervikmõtet), avatud kodeerimine, koodide jaotamine alakategooriatesse, peakategooriate moodustamine ning tulemuste esitamine ja interpreteerimine (ibid.). Andmed kodeeriti vabavaralise andmetöötluskeskkonna QCAmap abil, mida Mayring (2014) soovitab kasutada tekstide analüüsimiseks induktiivsel meetodil. Andmeanalüüsi käigus tekkis kolm peakategooriat (soolise võrdõiguslikkuse tajumine ühiskonnas, 
soolise võrdõiguslikkuse tajumine hariduses ja soolise võrdõiguslikkuse roll õpetajakoolituses) ning viis alakategooriat. Tulemused esitatakse uurimisküsimuste kaupa, selgitades neid nii ankeetküsitluse andmestiku kui ka fookusrühma intervjuude näitel. Viimaste ilmestamiseks esitatakse ka tekstinäiteid, mille juurde on lisatud vastaja sugu $(\mathrm{M} / \mathrm{N})$ ja intervjuu number (nt F1).

\section{Tulemused}

\section{Üliõpilaste hoiakud soolise võrdõiguslikkuse suhtes}

Andes hinnanguid naiste ja meeste positsioonile Eesti ühiskonnas tervikuna, peavad üliõpilased meeste olukorda paremaks kui naiste oma. Seejuures hindavad naisüliõpilased meeste positsiooni ühiskonnas naiste omast paremaks oluliselt sagedamini kui meesüliõpilased (keskmine 4,0 vs. $\left.3,5^{\star 4}\right)$. Sama muster iseloomustab õpetajakoolituse üliõpilaste hinnanguid. Naiste ja meeste positsiooni tajub võrdväärsena ainult 17\% õpetajakoolituse üliõpilastest (vt tabel 1).

Tabel 1. Üliõpilaste hinnangud naiste ja meeste positsioonile Eesti ühiskonnas (\%)

\begin{tabular}{l|c|c|c|c|c}
\hline & $\begin{array}{c}\text { Nais- } \\
\text { üli- } \\
\text { õpilased }\end{array}$ & $\begin{array}{c}\text { Mees- } \\
\text { üli- } \\
\text { opilased }\end{array}$ & $\begin{array}{c}\text { Õpetaja- } \\
\text { koolituse } \\
\text { üliõpilased }\end{array}$ & $\begin{array}{c}\text { Teiste eri- } \\
\text { alade üli- } \\
\text { õpilased }\end{array}$ & Kokku \\
\hline $\begin{array}{l}\text { Naistel märgatavalt parem kui } \\
\text { meestel }\end{array}$ & $0^{*}$ & $2^{*}$ & 1 & 1 & 1 \\
\hline Naistel natuke parem kui meestel & $2^{*}$ & $9^{*}$ & 5 & 5 & 5 \\
\hline $\begin{array}{l}\text { Naised ja mehed on ühiskonnas } \\
\text { võrdväärsed }\end{array}$ & $14^{*}$ & $35^{*}$ & 17 & 23 & 22 \\
\hline Meestel natuke parem kui naistel & $63^{*}$ & $47^{*}$ & 51 & 57 & 56 \\
\hline $\begin{array}{l}\text { Meestel märgatavalt parem kui } \\
\text { naistel }\end{array}$ & $21^{*}$ & $8^{*}$ & 27 & 15 & 16 \\
\hline Kokku & 100 & 100 & 100 & 100 & 100 \\
\hline Keskmine & 4,0 & 3,5 & 4,0 & 3,8 & 3,8 \\
\hline
\end{tabular}

Märkus. ${ }^{*}-p<0,05.5$

4 Tärn $\left(^{*}\right)$ märgib statistiliselt olulist erinevust rühmade vahel $p<0,05$ juures.

5 Keskmine väärtus on arvutatud viiepallilise hindamisskaala põhjal. 
Fookusrühma intervjuudest õpetajakoolituse üliõpilastega selgusid võimalikud põhjused, miks üliõpilased tajuvad naiste ja meeste positsiooni ühiskonnas ebavõrdsena. Õpetajakoolituse üliõpilased tõid esile soorollide jäikuse ja hõlpsasti taastoodetavad soolised stereotüübid. Nad leidsid, et ebavõrdsust toidab soo alusel eristav mõtteviis, mis on levinud nii koduses kasvatuses kui ka koolis.

Näiteks põhi- ja keskkoolis on olnud olukordi, kus poisid, sh ma ise, oleme saanud teatud privileege või võinud käituda teatud moodi ilma karistuseta. Lisaks on sugu mänginud olulist rolli olukordades, kus oodatakse otsustavat käitumist, ja siis on vaadatud minu kui mehe poole. (M, F4)

Ma väga väärtustan naiseks olemist, aga mulle tundub, et mul on naisena ennast keerulisem karjäärialaselt kehtestada: normid on kõrgemal kui meestel, ebaõnnestumisi naiste puhul ei tolereerita, küll aga meeste juures. Ka ülikoolis paistab nii, et need üksikud noormehed, kes õpetajakoolituses õpivad, valmistuvad justkui koolijuhi rolliks ja naised siis reaõpetajaks. (N, F4)

Kirjeldades oma varasemat hariduskäiku, leidsid üliõpilased, et nad on soolise ebavõrdsusega mingil määral kokku puutunud. Üldhariduse omandamisel on nende meelest soopõhine eelistamine üsna tavaline nähtus, ning kui selle taga on tunnustatud õpetaja, siis probleemid pigem vaikitakse maha. Soopõhise eelistamise all peeti silmas alandavaid märkusi, ignoreerimist ja/või ebaõiglast hindamist soo alusel. Kõigis fookusrühmades jõudis jutt soopõhiste piiranguteni õppeainete valimisel, nt poisid said võimaluse tööõpetuse raames puutööd õppida, samal ajal kui tüdrukud tegelesid kokandusega. Õpilaste soopõhist jaotamist tööõpetuse ja kodunduse tundides peeti soolise võrdõiguslikkuse rikkumiseks koolis.

Soolist ebavõrdsust tingiva peamise aspektina nimetasid õppurid õpetajate orienteeritust poistele või liigse tähelepanu suunamist meesüliõpilastele. Ülikoolis kogetu iseloomustamiseks tõid uuritavad näiteid õppejõudude kohatute soopõhiste kommentaaride ja sarkastiliste naljade kohta.

Mul oli matemaatikas nii, et õpetaja tegeles ainult poistega. Tüdrukud pidid tihtipeale ise óppima ja hakkama saama. (N, F2)

Mul on ühest kursusest näide, kus õppejõud järjest tegi nalju naiste pihta. Ma hakkasin neid märkusi kirja panema. Eelmine nädal sain viienda „nalja”: ... „lähete mootorit parandama, poisid, teie kindlasti teate. Tüdrukud, te ei tea midagi." (N, F2) 
Seega tajuvad üliõpilased (sh õpetajakoolituse üliõpilased) üldiselt meeste ja naiste positsiooni ühiskonnas ebavõrdsena ja seda pigem meeste kasuks. Oma haridustee kogemustele ja tähelepanekutele tuginedes osutasid õpetajakoolituse üliõpilased mitmel juhul eelkõige sotsiaalselt konstrueeritud soostereotüüpsuse avaldumisele hariduselus, kus piiratakse nii poiste/ meeste kui ka tüdrukute/naiste potentsiaali realiseerumist ning seatakse esiplaanile soo põhjal eristavad tunnused.

Samal ajal selgub ankeetküsitlusest, et üliõpilased suhtuvad soolisesse võrdõiguslikkusesse väga pooldavalt. Peaaegu kõik üliõpilased (95\%) nõustuvad, et hea ühiskonna tunnuseks on naiste ja meeste võrdsed võimalused. Suurem osa (87\%) üliõpilastest jagab seisukohta, et ühiskond, kus naised ja mehed on võrdsed, on hea ühiskond. Seejuures on soolist võrdõiguslikkust tunnustavad hoiakud mitmel viisil omavahel seotud. Näiteks need üliõpilased, kes nõustuvad väitega, et hea ühiskond on see, kus mehed ja naised on võrdsed, näevad hea ühiskonna tunnusjoonena ka naiste ja meeste võrdseid võimalusi $\left(r=0,53^{\star}\right)$. See osa õppuritest:

a) on veendunud, et naiste ja meeste võrdõiguslikkusest võidavad ka mehed $\left(r=0,48^{\star}\right)$;

b) ei jaga seisukohta, et soolist võrdõiguslikkust takistab meeste ja naiste bioloogiline erinevus $\left(r=-0,47^{\star}\right)$;

c) ei jaga seisukohta, et sooline võrdõiguslikkus ei ole võimalik, sest naistel ja meestel peavad olema ühiskonnas eri rollid $\left(r=-0,42^{\star}\right)$.

Need üliõpilased (20\%), kes ei usu soolisse võrdõiguslikkusesse, leides, et naistel ja meestel peavad ühiskonnas olema eri rollid, arvavad ühtlasi, et meestel peabki olema kõrgem palk, kuna nad peavad üleval oma peret $\left(r=0,33^{\star}\right)$. Samuti ei ole neil usku, et naised saavad tehnilisi oskusi nõudvatel töökohtadel sama hästi hakkama kui mehed $\left(r=-0,34^{\star}\right)$, ning nad on veendumusel, et koduste tööde eest peaks peamiselt vastutama naine $\left(r=0,4^{\star}\right)$. Soolise võrdõiguslikkuse suhtes konservatiivne rühm leiab veel, et tüdrukutele ja poistele ei tohiks samu õppeaineid õpetada ühesugusel viisil $\left(r=-0,31^{\star}\right)$, ning avaldab arvamust, et karjäärivalikul peaksid poisid mõtlema tulevase sissetuleku suurusele rohkem kui tüdrukud $\left(r=0,4^{\star}\right)$.

Analüüsi põhjal joonistub selgelt välja seos stereotüüpsete hoiakute vahel: üliõpilased, kes leiavad, et sooline võrdõiguslikkus ei ole võimalik meeste ja naiste bioloogiliste erinevuste tõttu (neid on tervelt kolmandik ehk 32\%), on veendunud ka selles, et sooline võrdõiguslikkus ei ole võimalik, sest naistel ja meestel peavad olema ühiskonnas eri rollid $\left(r=0,6^{\star}\right)$. Arvamused erinevad soopõhiselt - rohkem nõustuvad sellise väitega meessoost üliõpilased. 
Mõtiskledes soolist võrdõiguslikkust takistavate tegurite üle, mainisid ka õpetajakoolituse üliõpilased meeste ja naiste bioloogilisi ja füsioloogilisi eripärasid, mida peab iga otsuse ja tegevuse puhul arvesse võtma. Nende hinnangul on sooliste aspektidega arvestamine võrdõiguslikkuse tagamise juures kõige keerulisem. Siinjuures eristus soostereotüüpne mõtlemine, mille korral markeeriti bioloogilised erinevused paratamatu takistusena sugudevahelise võrdväärsuse saavutamisel ning jagati arusaama, et soost tingitud eripärade tõttu ei saa kõiki võrdsetel alustel hinnata.

Neid asju on ju väga palju, millega peab arvestama. Juba alates põhikoolist peab arvestama füsioloogiliste erinevustega. Ei saagi võtta täiesti võrdselt. Teada on, et naised arenevadki kiiremini, ning kehalises kasvatuses panna samad tulemused ette ja selle järgi hinnata ei ole võimalik. (M, F1)

Näiteks sõjaväes tulid välja konkreetsed naiste füsioloogilised miinused meeste ees, mitte lihtsalt lihasramm või miski muu, vaid selline lihtne näide ... Achilleuse kõõlust vigastavad naised palju kiiremini, kui nad pikki maid peavad kõndima. (M, F2)

Sarnaseid näiteid tõid üliõpilased pea kõigis fookusrühmades. Siit nähtub, et hoolimata sellest, et üliõpilased üldkogumina on soolise võrdõiguslikkuse suhtes väga pooldavad, leidub nende seas ka traditsioonilise, meeste ja naiste maailma ning soorolle rangelt eristava vaate pooldajaid.

Fookusrühma aruteludest selgus, et sõnavabadus, kontakt välismaailmaga, võimalus suhelda inimestega, kel on erinev maailmavaade, ja vaba meedia on soodustanud soolise võrdõiguslikkuse idee levikut ning see eristab tänapäeva üliõpilasi nende vanemate põlvkonnast. Samuti on õpetajakoolituse üliõpilased märganud uute arvamusliidrite esilekerkimist, seades neid eeskujuks ülejäänud elanikkonnale.

Sellele [soolisele võrdõiguslikkusele] aitab kaasa ka võimupositsioonidel olevate inimeste põlvkonnavahetus ning tänapäeva väärtusliidrid ja juhid on enamjaolt juba tolerantsed ja pooldavad soolist võrdõiguslikkust. (M, F4)

Fookusrühmade üliõpilased tõid näiteid, mis kinnitavad muutusi soolise võrdõiguslikkuse idee juurdumisel. Eriti positiivse eeskujuna tajuvad nad üldsusele tuntud mehi, kes võtavad meelsasti lapsepuhkust ja näitavad end soonormi tavadega võrreldes erinevas rollis. 
Suur oli minu üllatus, kui eelmisel aastal oli Õpetajate Lehes haridusministri Jevgeni Ossinovski pilt oma vastsündinud beebiga ja teatega, et minister läks kuuenädalasele isapuhkusele. Enam paremat rollikuvandit ühiskonnale pole võimalik pakkuda. (N, F4)

Õpetajakoolituse üliõpilased leidsid, et julge ühiskonna tunnuseks on tänapäevase peremudeli muutumine soolise võrdõiguslikkuse alustalaks, kus mõlemad vanemad panustavad võrdväärselt kodu toimimisse. Meedia kõrval kirjeldasid üliõpilased positiivselt ka uusi õpikuid ja töövihikuid, kus kajastatakse soorolle tavapärasest erinevas võtmes.

Mulle hakkas just koolipraktikal silma, et vähemalt inimeseõpetuse uued õpikud on n-ö poliitiliselt korrektsed. Kõik rollid on vanade arusaamadega võrreldes muutunud: isad sõidavad lapsevankriga ja emad keeravad lambipirne jne. (M, F4)

Me ei räägi enam eelmise sajandi võtmes, kus naise kohus oli olla köögis ja süüa teha ning maja hoida ja mehe ülesanne oli perele raha teenida. Nüüdseks on need rollid võrdsustunud ja mõlemad vanemad panustavad võrdselt nii oma kodu loomisesse kui leiva lauale toomisesse. $(\mathrm{N}, \mathrm{F} 3)$

Soolist võrdõiguslikkust soodustava asjaoluna toovad üliõpilased välja uued karjäärivalikud. Nende arvamuse kohaselt aitavad soolist jäikust ühiskonnas pehmendada inimesed, kes valivad soonormidest erinevad ametialad.

Kokkuvõtvalt jäid kõlama ideed, et sooline võrdõiguslikkus on pigem seotud noorema põlvkonna julgemate haridus- ja ametivalikutega ning uue peremudeli ja abikaasadevahelise tööjaotusega.

\section{Üliõpilaste teadlikkus eriala ja tööturuga seotud soolisest võrdõiguslikkusest}

Eri väidetele soolise võrdõiguslikkuse kohta tõest või väära hinnangut andes võib üliõpilaste vastustele tuginedes järeldada, et kõige üldisemal tasandil on Eesti üliõpilaskonna teadmised soolise võrdõiguslikkuse põhimõtetest head - teatakse, et võrdõiguslikkus on inimõigus (88\%) ja on olemas soolist diskrimineerimist keelustav seadus (79\%) (vt vastuste üldist struktuuri jooniselt 2). Ka õpetajakoolituse üliõpilaste tööturuteadlikkust iseloomustas sama tendents ning teiste valdkondade üliõpilastega võrreldes statistiliselt olulisi erinevusi vastustes ei esine, kuid mõned nüansid saab esile tõsta. 
Eestis on olemas seadus, mis keelustab soolise diskrimineerimise

Kui tööandja hinnangul teevad ühe soo esindajad mõnda tööd paremini kui teise soo esindajad, on tal õigus valida töötaja tema soo järgi

Meeste ja naiste võrdne kohtlemine on inimõigus

Tööandja võib töökuulutuses märkida, mis soost töötajat ta otsib

Kui naistöötaja küsib madalamat palka kui sama tööd tegev meestöötaja, siis võib talle madalamat palka maksta

Töövestlusel võib küsida kandidaadilt tema eraelu, nt abieluaastate ja lastesaamisplaanide kohta

Tööandja tohib eelistada ilma lasteta töötajat, kui tema hinnangul saavad tööülesanded sel viisil paremini täidetud

Lapsepuhkuselt naasvale töötajale võib maksta madalamat palka, sest tema oskused ja teadmised on eemaloleku ajal rooste läinud

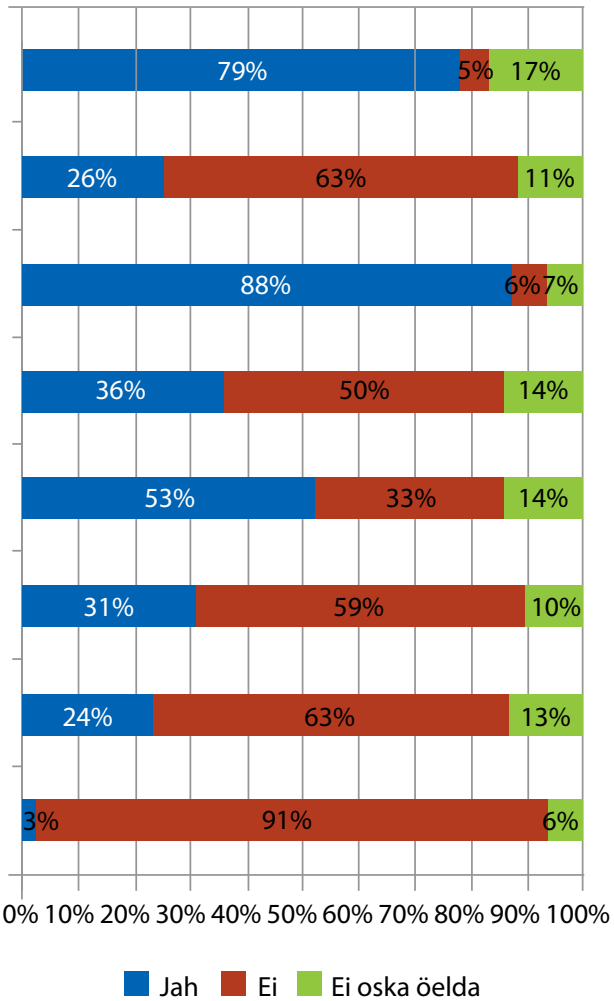

Joonis 2. Üliõpilaste hinnangud soolise võrdõiguslikkusega seotud väidetele

Õpetajakoolituse üliõpilased on teadlikud, et sugupoolte võrdne kohtlemine on inimõigus ja Eestis on olemas seadus, mis keelustab soolise diskrimineerimise. Samas on tähelepanuväärne, et tervelt ligi neljandik (23\%) õpetajakoolituse üliõpilastest ei ole sellise seaduse olemasolust teadlik: nendest enamik (19\%) ei oska sellise seaduse olemasolu kohta seisukohta võtta ning 5\% arvab, et sellist seadust ei ole Eestis olemas. Teiste valdkondade üliõpilastega võrreldes on õpetajakoolituse üliõpilased teadlikumad, et sugupoolte võrdne kohtlemine on inimõigus (96\% vs. 87\%), kusjuures vaid $2 \%$ ei oska selle väite puhul seisukohta võtta ning $2 \%$ ei pea meeste ja naiste võrdset kohtlemist inimõiguseks. Teiste valdkondade üliõpilaste puhul on need näitajad $7 \%^{*}$ ja $6 \%$.

Kogu üliõpilaskonnast usuvad rohkem kui pooled (53\%), et sama töö eest võib mehele ja naisele maksta erinevat palka, ja nad ei tea, et värbamisel ei tohi eelistada ühest soost töötajat teisele (50\%). Õpetajakoolituse üliõpilaste seas on tööturualane sooteadlikkus pisut suurem võrreldes teiste valdkondade üliõpilastega: ekslikul arusaamal, et soo alusel võib töötajale erinevat tasu maksta, on vähem kui pooled õpetajakoolituse üliõpilastest (41\% vs. 53\%). 
Sarnane muster ilmneb õpetajakoolituse üliõpilaste ja teiste õppekavade üliõpilaste võrdluses ka tööandja personaalsete tõekspidamiste puhul. Kui teiste valdkondade üliõpilastest näib sooline eelistus töötaja valimisel seaduslik neljandikule $\left(27 \%^{*}\right)$, siis õpetajakoolituse üliõpilastest jagab seda eksiarvamust vaid kümnendik $\left(12 \%^{*}\right)$. Siinjuures on oluline märkida, et mõlema rühma üliõpilaste puhul on rohkem kui kümnendik (vastavalt 11\% ja $12 \%)$ neid, kes ei osanud vastata, kas tööandjal on õigus valida töötajat soo järgi, kui ta hindab, et ühe soo esindajad teevad seda tööd paremini, või mitte. Need üliõpilased, kes arvavad, et värbamisel võib rakendada soolist eelistust, usuvad ka, et kui tööandja hinnangul teevad ühe soo esindajad mõnda tööd paremini, siis on tal õigus valida töötaja soo alusel $\left(r=0,31^{\star}\right)$.

Suur osa üliõpilastest on ekslikul arvamusel, et tööandjal on õigus teada nende eraelulisi küsimusi ja sellest tulenevalt on tööandjal õigus võtta neid töötaja valikul arvesse. Tervelt kolmandik (31\%) üliõpilastest peab tõeseks, et töövestlusel võib tööandja küsida eraelu (nt abielustaatuse ja lastesaamisplaanide) kohta, kusjuures kümnendik ei ole kindel, kas see on seaduslik või mitte. Sarnane muster iseloomustab õpetajakoolituse üliõpilasi.

Neljandik (24\%) kõigist üliõpilastest usub, et tööandja tohib eelistada ilma lasteta töötajat, õpetajakoolituse üliõpilaste seas on sellise arusaamaga viiendik (18\%). Need üliõpilased, kes on arvamusel, et töövestlusel võib kandidaadi eraelu kohta küsida, arvavad ka, et tööandjal on soovi korral õigus eelistada ilma lasteta töötajat $\left(r=0,40^{\star}\right)$ ning töökuulutuses on seadusega lubatud soolist eelistust märkida $\left(r=0,31^{\star}\right)$. Võrreldes teiste tööturualaste teadmistega soolise võrdõiguslikkuse kohta on enamik üliõpilastest (91\%) väga hästi informeeritud sellest, et lapsepuhkuselt naasvale töötajale ei tohi maksta madalamat palka.

Kvalitatiivses uuringus osalenud õpetajakoolituse üliõpilased märkisid, et nad tajuvad soolist ebavõrdsust tööturul väga selgelt, eelkõige värbamispoliitika ja soolise palgalõhe kujul. Eesti olukorda analüüsides meenutati juhtumeid, mil on märgatud soolise diskrimineerimise ilminguid tööturul.

Ma sooviksin, et sooline võrdõiguslikkus on meie ühiskonnas pigem norm ja tavaarusaam, mitte poliitiline slogan. Mind väga häiris, kui Tallinna koolis, vist GAGis, oli see meeskoka töökuulutus, mis palju pahandust tekitas. See oli solvav, teades, et head tippkokad võivad ka naised olla - miks ei ole meie ühiskond nii küps, et kellelgi võib üldse selline idee tulla. (N, F4)

Ikkagi see palgalõhe teema. See ei ole normaalne, et samaväärset tööd tehes on nii suur palgavahe meestel ja naistel. Jällegi Eestis keskmiselt 
kõrgem kui mujal. Arvan, et selle poole peaks küll püüdlema, et võrdse haridusega ja võrdse töökoormuse juures on ka palk ühesugune. Muidu joonistub meie pealt välja Ida-Euroopa muster, aga mitte Põhjamaade, kuhu me tahaks kuuluda. (M, F2)

Tulemused osutavad, et õpetajakoolituse üliõpilaste teadlikkus soolisest võrdõiguslikkusest tööturul on suur, kasvades praktilise (õpetamis)kogemusega. Üliõpilased oskasid elavalt kirjeldada selleteemalisi arutelusid meedias, karjääripäevadel ja kursustel.

Küsides üliõpilaste hinnanguid erialaõpingute jooksul soolise võrdõiguslikkuse valdkondade (inimõiguste, lapse õiguste, soolise ebavõrdsuse, võrdse kohtlemise, feminismi) käsitlemise kohta, selgub, et kõige sagedamini on ülikooli loengutes või seminarides räägitud inimõigustest ja kõige vähem feminismist (vt tabel 2). Õpetajakoolituse üliõpilaste ja teiste erialade üliõpilaste võrdluses ilmnevad statistiliselt olulised erinevused kahe teema puhul. Õpetajakoolituse üliõpilased on võrreldes õpingukaaslastega teistelt erialadelt kuulnud rohkem lapse õiguste teemast $\left(2,6\right.$ vs. $\left.1,7^{\star}\right)-$ ülikoolis on sellest kuulnud enamik õpetajakoolituse üliõpilastest (84\%), kümnendik on osalenud selleteemalisel eraldi kursusel. Õpetajakoolituse üliõpilased on teiste erialade üliõpilastega võrreldes kuulnud vähem soolisest võrdõiguslikkusest ühiskonnas $\left(1,7 v s .1,8^{\star}\right)$. Feminismi teemaga on kokku puutunud vaid kolmandik (34\%) õpetajakoolituse üliõpilastest. Rohkem kui pool üliõpilaskonnast tunnistab, et neile ei ole feminismist ega lapse õigustest loengute-seminaride raames üldse räägitud (vastavalt 61\% ja $52 \%)$.

Tulemused näitavad, et kui üliõpilastele on ülikooli loengutes või seminarides räägitud ühel teemal (nt inimõigused või võrdne kohtlemine), siis on käsitletud ka teisi valdkondi (korrelatsioonid viie teema vahel vahemikus $\left.0,4-0,8^{\star}\right)$. Kõige tugevam seos $\left(r=0,8^{\star}\right)$ on võrdse kohtlemise ja soolise ebavõrdsuse valdkonna vahel.

Ka fookusrühma intervjuudest õpetajakoolituse üliõpilastega nähtub, et bakalaureuseastme õppurite kokkupuude soolise võrdõiguslikkuse valdkondadega on napp, samas kui õpetajakoolituse magistriastme üliõpilased on soolise võrdõiguslikkuse teemadest oluliselt teadlikumad. Magistrandid nimetasid oma stuudiumist selliseid ainekursusi nagu „Ôpilaste individuaalsed iseärasused”, „Multikultuuriline haridus” ja „Võrdlev koolikorraldus", kus soolise võrdõiguslikkuse valdkondi on käsitletud. Samuti toodi välja ajaloo didaktika, mille raames on nende teemade üle arutletud. Õpetajakoolituse üliõpilaste teadlikkust sellest teemast on mõjutanud koolipraktika, mida käsitletakse täpsemalt järgmises alapeatükis. 
Tabel 2. Üliõpilaste hinnangud soolise võrdõiguslikkuse valdkondade käsitlemisele erialaõpingute ajal (\%)

\begin{tabular}{l|c|c|c|c|c}
\hline & $\begin{array}{c}\text { Inim- } \\
\text { õigused }\end{array}$ & $\begin{array}{c}\text { Lapse } \\
\text { õigused }\end{array}$ & $\begin{array}{c}\text { Sooline } \\
\text { ebavõrdsus } \\
\text { ühiskonnas }\end{array}$ & $\begin{array}{c}\text { Võrdne } \\
\text { kohtle- } \\
\text { mine }\end{array}$ & $\begin{array}{c}\text { Femi- } \\
\text { nism }\end{array}$ \\
\hline Üldse ei räägitud & 30 & 52 & 40 & 37 & 61 \\
\hline Mõne kursuse raames põgusalt & 37 & 27 & 41 & 39 & 27 \\
\hline Mõne kursuse raames põhjalikult & 24 & 17 & 16 & 21 & 10 \\
\hline Eraldi kursus sel teemal & 9 & 5 & 3 & 3 & 3 \\
\hline Kokku & 100 & 100 & 100 & 100 & 100 \\
\hline Ei oska vastata & 3 & 3 & 3 & 3 & 4 \\
\hline Keskmine & 2,11 & 1,74 & 1,81 & 1,89 & 1,54 \\
\hline Standardhälve & 0,94 & 0,89 & 0,80 & 0,82 & 0,77 \\
\hline $\begin{array}{l}\text { Õpetajakoolituse üliõpilased } \\
\text { (keskmine }\end{array}$ & 2,09 & $2,56^{*}$ & $1,69^{*}$ & 1,89 & 1,45 \\
\hline $\begin{array}{l}\text { Teiste erialade üliõpilased } \\
\text { (keskmine7) }\end{array}$ & 2,12 & $1,69^{*}$ & $1,82^{*}$ & 1,89 & 1,55 \\
\hline
\end{tabular}

Märkus. * $-p<0,05$.

Positiivse näitena erialase teemakäsitluse kohta meenutasid üliõpilased ühe välisõppejõu loengut, kus elavat diskussiooni tekitas Austria uus kõrghariduspoliitika, mille kohaselt soovitakse akadeemilist kraadi eeldavatele ametikohtadele tuua rohkem naisi, kehtestades selleks kvoodid. Sookvootide rakendamise praktika tekitas üliõpilastes huvi ja suunas neid teemat analüüsima võrdlevas perspektiivis. Üliõpilased rõhutasid, et väga oluline on tuua tulevased õpetajad teema juurde intrigeerivate ülesannete, diskussiooni ja sotsiaalsete eksperimentide kaudu, kus pannakse küsimärgi alla ka nende endi uskumused.

\section{Üliõpilaste ootused ja hoiakud soolise võrdõiguslikkuse käsitlemiseks erialaõpingute ajal}

Üliõpilaste suhtumine sooteema lõimimisse õppekavva ja uurimistööde valdkonda on üldjoontes toetav. Ankeetküsitlusest selgub, et need üliõpilased, kes hindavad meeste positsiooni ühiskonnas paremaks kui naiste oma,

6 Keskmine väärtus on arvutatud viiepallilise hindamisskaala põhjal.

7 Keskmine väärtus on arvutatud viiepallilise hindamisskaala põhjal. 
nõustuvad oluliselt sagedamini väidetega, et haridusvaldkonnas on probleeme soolise ebavõrdsuse või diskrimineerimisega $\left(r=0,3^{*}\right)$ ning erialaõpingutes on vajalik käsitleda soolise võrdõiguslikkuse teemat $\left(r=0,4^{\star}\right)$. Samuti on see üliõpilasrühm valmis osalema ise ainekursusel, kus käsitletakse soolist võrdõiguslikkust $\left(r=0,4^{\star}\right)$. Seega, üliõpilased, kes hindavad meeste positsiooni ühiskonnas pisut paremaks kui naiste oma, on teadvustanud soolise ebavõrdsuse probleemi oma valdkonnas, tunnevad kaasüliõpilastega võrreldes suuremat vajadust ülikooli pakutavate teemakohaste ainekursuste järele ning eeldavad, et erialal töötamiseks on sellealased teadmised vajalikud.

Teiste erialade üliõpilastega võrreldes on õpetajakoolituse üliõpilaste ootused sooteema käsitlemiseks ainekursustel suuremad. Õpetajakoolituse õppurid leiavad sagedamini, et oma erialal töötamiseks on vaja teadmisi soolisest võrdõiguslikkusest (keskmine 3,21 vs. 2,88*), ja nõustuvad rohkem väitega, et nende valdkonnas on probleeme soolise ebavõrdsuse või diskrimineerimisega (keskmine 2,72 vs. 2,49*). Samuti avaldavad nad rohkem soovi võtta õppeainet, kus käsitletakse soolist võrdõiguslikkust seoses nende erialaga (keskmine 3,14 vs. 2,82*).

Üliõpilaskonna üldise hinnangu kohaselt on sooteemat valdkonna uurimistöödesse võimalik lõimida, seejuures hindavad õpetajakoolituse üliõpilased seda vajadust pakilisemaks kui teiste valdkondade üliõpilased (keskmine 3,1 vs. 2,7*). Samas on seda võimalust seni tagasihoidlikult kasutatud. See tendents on iseloomulik kogu üliõpilaskonnale, kuigi hinnangud võimalusele sooteemat oma uurimistöösse lõimida on üsna heterogeensed (vt tabel 3). Seega peab enamik üliõpilastest sooteemat küll oluliseks (69\% vastas „Jah, kindlasti” või „Pigem jah”), kuid oma uurimistöösse on seda lõiminud vähem kui viiendik (19\%).

Tabel 3. Üliõpilaste arvamused sooteema lõimimisest uurimistöödesse (\%) ${ }^{8}$

\begin{tabular}{l|c|c|c}
\hline & Õpetajakoolituse üliõpilased & Teiste erialade üliõpilased & Kokku \\
\hline Jah, kindlasti & 29 & 29 & 29 \\
\hline Pigem jah & 54 & 32 & 33 \\
\hline Pigem mitte & 16 & 24 & 23 \\
\hline Kindlasti mitte & 1 & 15 & 14 \\
\hline Kokku & 100 & 100 & 100 \\
\hline Keskmine $^{8}$ & 3,1 & 2,7 & 2,8 \\
\hline Standardhälve & 0,69 & 1,04 & 1,02 \\
\hline
\end{tabular}

8 Keskmine väärtus on arvutatud viiepallilise hindamisskaala põhjal. 
Üliõpilastelt küsiti ka hinnangut oma valdkonna õppejõudude teadlikkusele soolise võrdõiguslikkuse teemast. Kui enamik hindab õppejõude "pigem teadlikuks”, siis on tähelepanuväärne, et veerand üliõpilaskonnast (23\% üldkogumist ja 26\% õpetajakoolituse üliópilastest) ei oska oma õppejõudude teadlikkusele sooteemast hinnangut anda. Siit järeldub, et üks eeldusi soolise võrdõiguslikkuse valdkonna paremaks lõimimiseks õppe- ja teadustöösse on teemat valdavate ja kasutama julgustavate õppejõudude olemasolu.

Intervjuudest õpetajakoolituse üliõpilastega ilmneb, et soolise võrdõiguslikkuse teemat on viimastel aastatel hakatud siiski käsitlema nii üksikute kursuste raames kui ka lõputöödes. Seetõttu on ka üliõpilaste endi teadlikkus kasvanud ning nad oskavad seda valdkonda seostada oma uurimisfookusega.

Seda teemat on hakatud uurima lõputöödes, just lugesin üht bakalaureusetööd „Soolistatud ootused koolis”, väga huvitav. Oleksin heameelega sellest valdkonnast oma magistritöö kirjutanud, aga siis kaks aastat tagasi - ei pakutud seda välja. (N, F3)

Ma uurisin ise oma bakalaureusetöös põhikooliõpilaste suhtumist spikerdamisse ja sealt tuli huvitavaid sooerinevusi välja. Ja mitte ainult Eestis, vaid ka Soomes, kust mu osad uuritavad pärit olid. $(\mathrm{M}, \mathrm{F} 4)$

Samas viidatakse, et mitte alati ei leidu selles valdkonnas pädevaid juhendajaid või siis kasutavad õppejõud aegunud õpetamismeetodeid.

Selge, et õpetajakoolitusest tuleb alustada. Aga väga oskuslikult, et ei hirmutataks nende „sookollidega”, et kõik oleks tasakaalus ja teaduslike uuringutega põhjendatud. (N, F2)

Asi ei tööta, kui õppejõud räägib, kuidas tema arust asjad peavad olema, ning ei anna võimalust tudengitel endil arvamust väljendada ning põhjendada ... või kui õppejõud ütleb, et nii on kuskil seaduses või õppekava üldosas kirjas ja teie peate sellest lähtuma. Ma tahaksin ikka mõista, miks, mis argumendid seal taga on, ja see enda jaoks läbi mõelda - ainult nii saan seda tõsiselt võtta. (N, F1)

Huvitava tendentsina selgub intervjuudest, et bakalaureuseastme üliõpilaste hulgas on neidki, kes leiavad, et soolise võrdõiguslikkuse lahkamisega ülikoolis on hiljaks jäädud ja tänapäeva noori see enam ei puuduta. 
Ma näen kaht tahku: kas on juba hiljaks jäädud või läheb see teema üksikutele korda. Kas see teema on vajalik ja peaks olema käsitletud ülikoolis või mitte? Ma ütleks ei. Need, kes on enda jaoks mõttemaailma kujundanud, nende jaoks kehtibki mõte, et naine peseb nõusid ja toob õlut. Teda ülikool ei aita. See inimene, kes on niikuinii avatud meeltega ja tolereerib kõiki, tema jaoks see ei annaks midagi. (M, F2)

Samas on magistriastme üliõpilased soolise võrdõiguslikkuse teema perspektiivikuse suhtes positiivsemad. Tänu läbitud koolipraktikale tajuvad nad palju selgemalt vajadust selliste kursuste järele, kus käsitletakse sootundliku hariduse teemasid. Üliõpilased kirjeldavad oma koolipraktika kogemusi, täpsemalt seda, kuidas õpetaja suutis kodust kaasa tulnud stereotüüpe kummutada, kui ta kasutas õigeid töövõtteid ja -vahendeid. Peamiselt rõhutatakse erinevate aktiivõppe meetodite rakendamise vajadust.

Kui kodust on mingid stereotüübid kaasa tulnud, siis õpetaja peab oskama neid leevendada. (N, F1)

Algklassides rakendati väga palju rühmatöid ... ja seeläbi õpiti rohkem arvestama üksteisega, kuulama teisi, mitte üksteise arvamust halvustama ... (N, F3)

Õigete ja asjakohaste töövõtete all peavad üliõpilased silmas head ettevalmistust algavaks tunniks, paindlikkust tunni läbiviimisel ja varieeruvaid meetodeid tunni teema käsitlemiseks. Samuti tõdevad nad, et õpikutel ja õppematerjalil on määrav tähtsus, kuna need kujundavad õpilaste esmast arusaama teemast.

Kõige keerulisemaks peavad õpetajakoolituse üliõpilased võrdset kohtlemist hindamisel. Õpetaja ei tohi õpilasi soopõhiselt eelistada ning peab pingutama, et õppeaine oleks kõigi jaoks huvitav. See tagab tulemuse, mille alusel saab kõiki õpilasi võrdselt hinnata.

Õpetajana sa ei tohi ju tegelikult vahet teha. Nad on ju võrdsed. Mina inimeseõpetuse õpetajana ei tohi kogu aeg rõhutada, milline võiks olla mees ja milline naine. (N, F1)

Ma plaanin poistelt samamoodi oodata häid tulemusi. Ehk olen ma idealist, aga ma pean ise ka väga palju pingutama ja vaeva nägema selleks, et nad tahavad minu tundi tulla. Aga kui ma ei pinguta ega näe vaeva, siis kümne aasta pärast istume siinsamas ruumis ja annan 
sama intervjuud, ainsa vahega, et mitte midagi pole muutunud ja võrdõiguslikkus on endiselt tabu. (N, F2)

Fookusrühma üliõpilastel paluti visandada oma ettekujutus heast ja atraktiivsest soolise võrdõiguslikkuse kursusest, kuhu nad meelsasti läheksid. Arutelust õppuritega selgub, et selline kursus peaks olema põnevalt üles ehitatud, kindlasti kombineeritud praktiliste harjutustega ja hõlmama aktiivõppe meetodeid.

Näiteks arutleda tõestisündinud juhtumite üle, et õppejõul on mingi juhtumite pank, kust ta siis neid „keisse” võtab ja aruteluks välja pakub. Nüüd on vist ka Youtube’i videod sooliste stereotüüpide kohta, kus näitlejad neid mängivad. Ka see oleks väga hea materjal seminaris koos vaatamiseks ja arutlemiseks. (M, F4)

Ootaks just diskussiooni ja sotsiaalseid eksperimente, kus pannakse küsimärgi alla tudengi enda uskumused. Oluline, et tulevane õpetaja leiaks üles enda stereotüübid, teadvustaks need. (N, F4)

Kui siit edasi fantaseerida, siis arutelu aluseks võivad olla ka mingid faktid, mis šokeerivad. Näiteks, et Eestis on suur sooline palgalõhe ning nüüd tuleks välja pakkuda mingid meetmed selle leevendamiseks või et kuidas tuua rohkem mehi kooli ... (N, F3)

Märkimisväärne osa õpetajakoolituse üliõpilaste teadlikkuse kujunemisel on täita koolipraktikal. Magistriastme üliõpilased, kes olid sooritanud koolipraktika, oskavad seada selgemaid nõudeid kursusele, kus käsitletakse sootundliku hariduse teemasid.

Seoses tundide ettevalmistusega lugesin hiljuti ülevaadet soorollidest õppekirjanduses ... seal olid väga head juhised, kuidas üldse hinnata õpikuid sellest aspektist ja eriti illustratsioone. Siit võiks tulla sisend mõnesse kursusesse, et õpetajakoolituse tudengid analüüsivad tänaseid õpikuid, siis oskavad nad ka õpetajana sellele rohkem tähelepanu pöörata. (N, F4)

Kokkuvõtvalt leidsid õpetajakoolituse üliõpilased, et õpetajaharidusel tervikuna on soolise võrdõiguslikkuse edendamisel oluline osa. Huvi selliste kursuste vastu tunnistasid kõigi fookusrühmade üliõpilased, seades suuri nõudmisi nii kursuste atraktiivsusele kui ka õppejõu õpetamispädevusele. Sobilikeks peeti aktiivõppe meetodeid, kus rakendatakse rühmatööd, diskussiooni, juhtumiarutelusid ja rollimänge. 


\section{Arutelu}

Haridus on valdkond, mis on soolise võrdõiguslikkuse edendamisel kesksel kohal. Õpetajate väärtustel ja hoiakutel on koolis toimuvale tugev mõju (Fraser \& Saunders, 1998, viidatud Chong \& Cheah, 2009 järgi), kuna soostereotüüpsed arusaamad kanduvad edasi ka õpetuse sisusse, koolikultuuri ja õpilaste hindamisse (Kütt \& Papp, 2012). Samuti toodavad ja kinnistavad levinud stereotüüpseid soorolle koolijuhtide hoiakud ja ootused, õppekavad, variõppekava ja õppematerjalid (Papp, 2012a). Samas on Eesti õpetajahariduses sooteema jäänud tagaplaanile: haridusvaldkonda reguleerivad dokumendid ei kajastata õpetajate (rääkimata õppejõudude) sooteadliku õpetamisviisi pädevust (Sugu ja soolisus ..., 2015). Samale tendentsile õpetajakoolituses osutavad ka mitmed rahvusvahelised uuringud. Sanders (2002) rõhutab, et sooteemat kaldutakse peitma mitmekesisuse eri tahkude taha, samuti viidatakse õppekavade ja -ainete ülekoormatusele ning levinud müüdile, nagu oleks sooline võrdõiguslikkus juba saavutatud (Kreitz-Sandberg, 2013; Lahelma 2014).

Siinse uurimuse eesmärk oli kirjeldada õpetajakoolituse ja kasvatusteaduste valdkonna üliõpilaste hoiakuid ja teadlikkust soolise võrdõiguslikkuse küsimuses, osutades nende erisustele üliõpilaste üldkogumist. Selle valdkonna üliõpilaste hoiakud soolise võrdõiguslikkuse suhtes on uurimistulemuste kohaselt toetavad: soolist võrdõiguslikkust peetakse oluliseks väärtuseks, ebavõrdses kohtlemises nähakse probleemi ning sageli osatakse ebavõrdset kohtlemist ka ära tunda ja märgata. Tulevaste õpetajate kriitilist lähenemist soolisele võrdõiguslikkusele peegeldab asjaolu, et meeste positsiooni ühiskonnas tajuvad nad paremana kui naiste oma. Sool põhinevat erinevat kohtlemist olid üldhariduskoolis otse või kõrvaltvaatajana tajunud ja kogenud paljud küsitlusele vastanud või fookusrühma intervjuudel osalenud üliõpilased, mis viitab sellele, et meie õpetajad kannavad endas soolisi stereotüüpe ja lähtuvad sageli neist oma töös (teadvustamata). Ôpilaste erinev kohtlemine koolis viib õppeedukuse, koolikeskkonna tajumise ja erialavalikute erinevuseni, mis omakorda mõjutab tugevalt õpilaste võimalusi tulevikus oma potentsiaali realiseerida (Ekström, 2010). Erinevast, soostereotüüpidel põhinevast kohtlemisest alguse saanud valikud aitavad säilitada ning halvemal juhul ka süvendada laiemaid ühiskondlikke valukohti, nagu sooline lõhe sissetulekutes, tasakaalust väljas peresisene tööjaotus või naiste ja meeste erinevad tervisenäitajad ja eluiga.

Fookusrühmade tulemuste analüüsist nähtus selgelt, et üliõpilaste hinnangul toidab ebavõrdsust soo alusel eristav mõtteviis, mis on levinud nii haridusasutustes kui ka koduses kasvatuses. Õpetajakoolituse 
üliõpilased nägid õpetajate ja õppejõudude meelestatust ning haridustee käigus kogetut soolist võrdõiguslikkust kujundava olulise tegurina. Seega on õpetajaid ettevalmistavatel kõrgkoolidel olemas vajalikud hoovad sootundlike ja -teadlike tulevaste õpetajate toetamiseks (Cushman, 2012; Kreitz-Sandberg, 2013). Õpetajakoolituse üliõpilastele peab pakkuma nii teoreetilisi teadmisi soolisest võrdõiguslikkusest, praktilisi oskusi soostereotüüpide, diskrimineeriva või mittesootundliku käitumise märkamiseks kui ka pedagoogilisi nippe sedalaadi olukordadega toimetulemiseks (Bondestam, 2010; Hynninen \& Juutilainen, 2006).

Soolise võrdõiguslikkuse lõimimisel õpetajakoolituse õppekavadesse tuleb arvestada üliõpilaskonna heterogeensusega. Kuigi üldiselt on üliõpilaste hoiakud soolise võrdõiguslikkuse suhtes soosivad, eristub selgelt rühm (viiendik kõigist küsitletutest), kelle suhtumine on pigem traditsioonilisi soorolle ja soostereotüüpseid valikuid soosiv. Samuti tuleb erialaõpingute programmide väljatöötamisel kasutada ja arvestada seda avaliku diskursuse potentsiaali, millele fookusrühmades osalenud õpetajakoolituse üliõpilased viitasid. Avalik infoväli, mis pakub näiteid soostereotüüpe eiravate valikute kohta, ning kokkupuude välismaailmaga on need hoovad, mis aitavad uuemal põlvkonnal olla soolise võrdõiguslikkuse printsiipide suhtes avatumad ning näha nende kasutegurit ja vajalikkust. Samuti viitab selline tulemus vajadusele soostereotüüpide murdmise ja soolise võrdõiguslikkuse lõimimise järele ühiskonnas, kuna laiem ühiskondlik kontekst mõjutab otseselt koolis toimuvat, õpetajate ja õpilaste valmisolekut ja vastuvõtlikkust uutele ideedele (Schalkwyk et al., 1997).

Õpetajakoolituse ja kasvatusteaduste valdkonna üliõpilaste soolist võrdõiguslikkust väärtustavad hoiakud, heal tasemel teadlikkus soolisest võrdõiguslikkusest tööturul ning huvi selle teema vastu loovad soodsa platvormi teema käsitlemiseks õpetajakoolituses.

Praegusest uurimusest nähtub, et üliõpilaste suhtumine sooteema lõimimisse õppekavva ja uurimistööde valdkonda on üldjoontes toetav, seejuures on õpetajakoolituse üliõpilastel suuremad ootused sooteema käsitlemise suhtes kui teiste erialade üliõpilastel. Tajutakse survet olla õpilastele eeskujuks, kardetakse taastoota jäiki ja traditsioonilisi soostereotüüpe. Samale tendentsile osutavad Fine-Davis ja Faas (2014), märkides, et ühiskonnas levinud soorollid on koolisüsteemis tugevalt juurdunud ning väheteadlikul õpetajal on oht suunata oma õpilasi tegema n-ö klassikalisi, soost lähtuvaid valikuid. Ka Papp (2013) tunnistab, et soorollide ootustest on keeruline välja murda.

Suhteliselt suurtest ootustest hoolimata on üliõpilaste reaalsed kokkupuuted soolise võrdõiguslikkuse valdkonnaga napid, nimetati vaid paari 
kursust, kus nendest teemadest on räägitud. Veidi üle veerandi üliõpilastest ei osanud oma õppejõudude teadlikkusele sooteemast üldse hinnangut anda, millest järeldub, et üks eeldusi soolise võrdõiguslikkuse valdkonna paremaks lõimimiseks õppe- ja teadustöösse on teemat valdavate ja kasutama julgustavate õppejõudude olemasolu.

Uuringus osalenud üliõpilased seadsid suuri nõudmisi eelkõige õppejõu õpetamispädevustele. Väärtustati aktiivõppe meetodeid, kus rakendatakse rühmatööd, diskussiooni, juhtumiarutelusid jms. Ka varasemad uuringud (Hedlin \& Åberg, 2012; hooks, 2010) kinnitavad, et loengumeetod ei sobi nende teemade käsitlemiseks ning tudengid saavutavad maksimaalse õpitulemuse dialoogi, mõttevahetuste ja erinevate ideede analüüsi kaudu. Õpetajahariduse õppejõud saavad rõhutada soolise võrdõiguslikkuse olulisust ja panna üliõpilased proovile, et nad õpiksid oma väärtusi tundma kriitilise pedagoogika raamistikus ja sotsiaalõiguslikus ruumis (hooks, 2010). Oluline on ka õppejõudude eeskuju. Nimelt ilmnes Poom-Valickise ja Löfströmi (2014) korraldatud uuringu põhjal selge seos enim üliõpilase kujunemist mõjutanud ainete ja seda õpetava õppejõu isikuga. Õppejõud pakuvad tulevaste õpetajate jaoks tähtsat eeskuju (Loughran \& Berry, viidatud Poom-Valickis \& Löfström, 2014 järgi), mõjutades nende professionaalse identiteedi kujunemist. Hedlin ja Åberg (2012) lisavad, et sooteema lahkamiseks õpetajakoolituses on vajalik pidev peegeldamine ja tagasisidestamine, mis eeldavad sügavat refleksiooni nii õppejõult kui ka üliõpilaselt.

Positiivsena selgus uuringust, et üliõpilased on entusiastlikud sooteemat oma valdkonna uurimistöödesse lõimima, seejuures hindasid õpetajakoolituse üliõpilased seda vajadust pakilisemaks kui teiste valdkondade üliõpilased. Samas on uurimistööde võimalust seni kasutatud tagasihoidlikult. Sarnasele tulemusele jõudis oma uuringus Isosomppi (2014), kes uuris, kas ja kuidas sugu ning soolisust on käsitletud Soome ülikoolide magistritöödes. Ka tema uurimistulemused kinnitasid, et üliõpilaste senine kogemus uurida sooteemasid on napp, ning siingi põhjendati seda õppejõudude vähese suunamisega.

Siinsest uuringust selgus, et tõkked ja tõrked soolise võrdõiguslikkuse teema lõimimisel õpetajakoolituse õppekavadesse ja uurimistööde temaatikasse on üliõpilaste hinnangul seotud õppejõududega. Eelkõige seostati seda nende puuduliku oskusega kursusele atraktiivset sisu kujundada ning sobivaid meetodeid valida. Samale tõdemusele on jõudnud mitmed teisedki uurijad, väites, et soolise võrdõiguslikkuse temaatikat peljatakse õpetajakoolituses, kuna see teema tekitab palju emotsioone, eeldades samal ajal ranget teaduspõhist käsitlusviisi (Butler, 2006; Zittleman \& Sadker, 2002; 
Weaver-Hightower, 2003; Younger \& Warrington, 2008). Sellest lähtudes võiks edasises uurimistöös keskenduda õppejõududele - sellele, milline on nende valmisolek sooteema käsitlemiseks ja üliõpilaste juhendamiseks ning kuidas vastastikuseid ootusi paremini harmoneerida.

\section{Tänusõnad}

Uuring on läbi viidud Poliitikauuringute Keskuse Praxis projekti „Soolise võrdõiguslikkuse lõimimine üld- ja kõrgharidusse" raames, mida rahastatakse Norra 2009.-2014. aasta toetuste soolise võrdõiguslikkuse ning tööja pereelu ühitamise programmist.

\section{Kasutatud kirjandus}

Aavik, K., \& Kajak, K. (2009). Soo sotsiaalne konstrueerimine Eesti lasteaedades 7 Tallinna lasteaia vaatlusandmete põhjal: empiiriline uurimus. Tallinn: ENUT.

Aavik, K., \& Uusma, H. (2014). Laste sotsialiseerimine. T. Roosalu (toim.), Soolise võrdõiguslikkuse monitooring 2013 (lk 26-35). Tallinn: Sotsiaalministeerium.

Anniste, K., Batueva, V., Biin, H., Mägi, E., Osila, L., \& Turk, P. (2016). Eesti üliõpilaste soolise võrdõiguslikkuse alane teadlikkus, hoiakud ja kogemused. Tallinn: Poliitikauuringute Keskus Praxis.

Anspal, S., Kraut, L., \& Rõõm, T. (2010). Sooline palgalõhe Eestis. Empiiriline analüüs. Tallinn: Centar/Praxis.

Bondestam, F. (2010). Kunskap som befrielse? En metaanalys av svensk forskning om jämställdhet och skola 1969-2009. SOU 2010:35.

Butler, J. (2006). Response. Special issue: Troubling identities: Reflections on Judith Butler's philosophy for the sociology of education. British Journal of Sociology of Education, 27(4), 529-534.

Chong, S., \& Cheah, H. M. (2009). A values, skills and knowledge framework for initial teacher preparation programmes. Australian Journal of Teacher Education, 34(3), 1-17. doi: http://dx.doi.org/10.14221/ajte.2009v34n3.1

Creswell, J. W. (2005). Educational research: Planning, conducting, and evaluating quantitative and qualitative approaches to research (2nd ed.). Upper Saddle River, NJ: Merrill/Pearson Education.

Creswell, J. W., Plano Clark, V. L., Gutmann, M., \& Hanson, W. (2003). Advanced mixed methods research designs. In A. Tashakkori \& C. Teddlie (Eds.), Handbook on mixed methods in the behavioral and social sciences (pp. 209-240). Thousand Oaks, CA: Sage.

Cushman, P. (2012). „You are not a teacher, you are a man”: The need for a greater focus on gender studies in teacher education. International Journal of Inclusive Education, 16(8), 775-790. doi: http://dx.doi.org/10.1080/13603116.2010.516774

Eesti teadlaste eetikakoodeks (2002). Eesti Teaduste Akadeemia. Külastatud aadressil http://www.akadeemia.ee/_repository/File/ALUSDOKUD/Eetikakoodeks2002.pdf. 
EIGE (European Institute of Gender Equality). Gender Equality Index. Retrieved from http://eige.europa.eu/content/gender-equality-index.

Ekström, A. (2010). Flickor, pojkar, individer - om betydelsen av jämställdhet för kunskap och utveckling i skolan. SOU 2010:99. Stockholm.

Elo, S., \& Kyngäs, H. (2008). The qualitative content analysis process. Journal of Advanced Nursing, 62(1), 107-115.

doi: http://dx.doi.org/10.1111/j.1365-2648.2007.04569.x

Eurobaromeeter 2010. Sooline võrdõiguslikkus EL-is aastal 2009: Eurobarometer 72.2 Eesti tulemused. Külastatud aadressil http://ec.europa.eu/public_opinion/archives/ebs/ebs_326_fact_ee_ee.pdf.

European Institute of Gender Equality (2015). Gender equality index 2015. Measuring gender equality in the European Union 2002-2012. Report. Retrieved from http://eige.europa.eu/sites/default/files/documents/mh0215616enn.pdf.

Eurostat (2015). Gender pay gap statistics. Retrieved from http://ec.europa.eu/eurostat/statistics-explained/index.php/Gender_pay_gap_statistics.

Fine-Davis, M., \& Faas, D. (2014). Equality and diversity in the classroom: A comparison of students' and teachers' attitudes in six European countries. Social Indicators Research, 119(3), 1319-1334.

doi: http://dx.doi.org/10.1007/s11205-013-0547-9

Hedlin, M., \& Åberg, M. (2012). Challenging gender in teacher education. In M. J. Samuelsson, C. Krekula, \& M. Åberg (Eds.), Gender and change: Power, politics and everyday practices (pp. 113-126). Karlstad: Karlstad University Press.

hooks, b. (2010). Teaching critical thinking: Practical wisdom. New York: Routledge.

Hynninen, P., \& Juutilainen, P.-K. (2006). Seitsemän asiaa ohjauksen suunnittelusta ja tasa-arvosta. Sukupuolisensitivinen ohjaus tasa-arvon edistäjänä koulutuksessa-hanke 2002-2006. Helsinki: Yliopistopaino.

Inglehart, R., \& Norris, P. (2003). Rising tide: Gender equality and cultural change around the world. Cambridge: Cambridge University Press. doi: http://dx.doi.org/10.1017/CBO9780511550362

Isosomppi, L. (2014). Gender as a theme and a concept in teacher students' Masters' theses. Proceedings of the 5th International Conference on Education and Educational Psychology (ICEEPSY 2014), 22nd - 25th October, Kyrenia, Cypros: Volume 2 (pp. 95-99). Future Academy: C-crcs Cognitive - Counselling Research \& Conference Services. Retrieved from http://www.futureacademy.org.uk/files/menu_items/other/FutureBook15.pdf.

Ivankova, N. V., Creswell, J. W., \& Stick, S. L. (2006). Using mixed-methods sequential explanatory research design: From theory to practice. Field Methods, 18(1), 3-20. doi: http://dx.doi.org/10.1177/1525822X05282260

Kreitz-Sandberg, S. (2013). Gender inclusion and horizontal gender segregation: Stakeholders' strategies and dilemmas in Swedish teachers' education. Gender and Education, 25(4), 444-465. doi: http://dx.doi.org/10.1080/09540253.2013.772566

Kruus, K. (2015). Soolise võrdõiguslikkusega seotud arusaamad õpetajakoolituse üliõpilaste näitel (magistritöö). Tartu Ülikool, Tartu. Külastatud aadressil http://dspace.ut.ee/handle/10062/48259.

Kütt, R., \& Papp, Ü-M. (2012). Sissejuhatus. Ü-M. Papp (toim.), Kas õpilased või poisid ja tüdrukud? Uurimus Eesti ópetajate ja haridustöötajate valmisolekust sootundlikuks õpetamiseks ja kasvatamiseks (lk 4-16). Tallinn: ENÜ. 
Lahelma, E. (2014). Troubling discourses on gender and education. Educational Research, 56(2), 171-183. doi: http://dx.doi.org/10.1080/00131881.2014.898913

Laherand, M-L. (2008). Kvalitatiivne uurimisviis. Tallinn: Infotrükk.

Mackevičiūtè, I. (toim.) (2008). Soolise võrdõiguslikkuse käsiraamat kohalikele omavalitsustele. Tallinn: Center for Equality Advancement.

Marling, R. (toim.) (2011). Sissejuhatus soouuringutesse. Tartu: Tartu Ülikooli Kirjastus.

Mayring, P. (2014). Qualitative content analysis: Theoretical foundation, basic procedures and software solution. Retrieved from http://nbn-resolving.de/urn:nbn:de:0168-ssoar-395173.

Milena, Z. R., Dainora, G., \& Alin, S. (2008). Qualitative research methods: A comparison between focus-group and in-depth interview. Annals of Faculty of Economics, 4(1), 1279-1283.

Pajumets, M., Aavik, K., Kus, L., Raudsepp, M., Kazjulja, M., Roosalu, T., \& Petersoo, P. (2013). Ebavõrdse kohtlemise märkamine ning teadlikkus võrdse kohtlemise seadusest: valdkondlike ekspertide kogemused ja hinnangud. K. Kallas, K. Kaldur, M. Raudsepp, T. Roosalu, \& K. Aavik (toim.), Võrdse kohtlemise edendamine ja teadlikkus Eestis (pp. 27-51). Tartu: Balti Uuringute Instituut.

Papp, Ü-M. (2012a). Kas õpilased või poisid ja tüdrukud? Uurimus Eesti õpetajate ja haridustöötajate valmisolekust sootundlikuks õpetamiseks ja kasvatamiseks. Tallinn: ENÜ.

Papp, Ü-M. (2012b). Ärka, märka, tegutse. Käsiraamat soolise võrdõiguslikkuse seaduse normide täitmiseks ja sugupoolte aspekti arvestamiseks üldhariduskoolide öppe- ja kasvatustöös. Tallinn: ENÜ.

Papp, Ü-M. (2013). Soouuringud haridus- ja kasvatusvaldkonnas. R. Mikser (toim.), Haridusleksikon (lk 228-233). Tallinn: Eesti Keele Sihtasutus.

Pehk, L. (2014). Soolõime käsiraamat. Kuidas võtta arvesse soolist aspekti arengukavades, Euroopa struktuuri- ja investeerimisfondide programmides ning projektides. Tallinn: Võrdõigusvoliniku kantselei.

Philips, K. (2007). Hüpoteeside testimine. Kogumite võrdlemine. Õppematerjal. TÜ ainekursus MJRI.01.024 Statistika.

Poom-Valickis, K., \& Löfström, E. (2014). Pikiuuring õpetajaks õppijate professionaalse identiteedi kujunemisest. Eesti Haridusteaduste Ajakiri, 2(1), 241-271. doi: http://dx.doi.org/10.12697/eha.2014.2.1.10

Promoting gender mainstreaming in schools. Final report of the Group of Specialists on Promoting Gender Mainstreaming in Schools (2004). Strasbourg: Directorate General of Human Rights.

Retrieved from https:/www.coe.int/t/dghl/standardsetting/equality/03themes/ gender-mainstreaming/EG-S-GS\%282004\%29RAPFIN_en.pdf.

Roosalu, T. (toim.) (2014). Soolise võrdõiguslikkuse monitooring 2013. Sotsiaalministeeriumi toimetised 3/2014. Tallinn: Sotsiaalministeerium.

Roosalu, T., Kall, K., \& Aavik, K. (2014). Soolise võrdõiguslikkuse kaheksa varjundit, sooülesed hoiakute koalitsioonid ja väärtuste tuum. T. Roosalu (toim.), Soolise võrdõiguslikkuse monitooring 2013 (lk 107-124). Tallinn: Sotsiaalministeerium.

Sanders, J. (2002). Something is missing from teacher education: Attention to two genders. Phi Delta Kappan, 84(3), 241-244. doi: http://dx.doi.org/10.1177/003172170208400314 
Schalkwyk, J., Thomas, H., \& Woroniuk, B. (1997). Handbook for the integration of a gender perspective in the education sector. Sida.

Skelton, C. (2007). Gender, policy and initial teacher education. Gender and Education, 19(6), 677-690. doi: http://dx.doi.org/10.1080/09540250701650599

Soolise võrdõiguslikkuse seadus (2004). Riigi Teataja I 2004, 27, 181. Külastatud aadressil https://www.riigiteataja.ee/akt/738642.

Sugu ja soolisus haridusvaldkonnas I. Üldharidus (2015). Külastatud aadressil http://www.vordoigusvolinik.ee/wp-content/uploads/2014/09/TEEMALEHTYldHaridus-I-pdf.pdf.

Zittleman, K., \& Sadker, D. (2002). Gender bias in teacher education texts: New (and old) lessons. Journal of Teacher Education, 53(2), 168-180. doi: http://dx.doi.org/10.1177/0022487102053002008

Tiidenberg, K. (2014). Heteronormatiivsus kui domineeriv hoiakutesüsteem Eestis 2013. T. Roosalu (toim.), Soolise võrdõiguslikkuse monitooring 2013 (lk 98-106). Tallinn: Sotsiaalministeerium.

Vainu, V., Järviste, L., \& Biin, H. (2010). Soolise võrdõiguslikkuse monitooring 2009. Tallinn: Sotsiaalministeerium.

Vidén, S., \& Naskali, P. (2010). Sukupuolitietoisuus Lapin Yliopiston Opettajankoulutuksessa. Lapin yliopiston kasvatustieteellisiä julkaisuja 22. Rovaniemi: Lapin Yliopiston Sukupuolentutkimusyksikkö.

Vihalemm, T. (2014). Fookusgrupi intervjuu. K. Rootalu, V. Kalmus, A. Masso, \& T. Vihalemm (toim.), Sotsiaalse analüüsi meetodite ja metodoloogia ópibaas. Külastatud aadressil https://sisu.ut.ee/samm/.

Võrdõigusvoliniku koduleht, Sooline võrdõiguslikkus. Külastatud aadressil http://www.vordoigusvolinik.ee/naiste-ja-meeste-vordoiguslikkus/soolisevordoiguslikkuse-moiste/.

Weaver-Hightower, M. B. (2003). The „Boy Turn” in research on gender and education. Review of Educational Research, 73(4), 471-498. doi: http://dx.doi.org/10.3102/00346543073004471

Younger, M., \& Warrington, M. (2008). The gender agenda in primary teacher education in England: Fifteen lost years. Journal of Education Policy, 23(4), 429-445. doi: http://dx.doi.org/10.1080/02680930802054396 


\title{
Gender awareness and attitudes toward gender equality among students participating in teacher training
}

\author{
Eve Mägi ${ }^{\mathbf{a} 1}$, Helen Biin ${ }^{\text {ab }}$, Karmen Trasberg ${ }^{c}$, Kersti Kruus ${ }^{d}$ \\ a Praxis Centre for Policy Studies \\ ${ }^{b}$ Institute of Social Studies, University of Tartu \\ ${ }^{c}$ Institute of Education, University of Tartu \\ ${ }^{d}$ Estonian Defence League
}

\section{Summary}

\section{Introduction}

Gender equality is regarded to be one of the core factors of any democratic society and the facilitator of economic growth and societal well-being. Although Estonia is often pointed out as a success story of post-socialist transformation, we are anything but successful when comparing different gender equality indicators of Estonia and other European countries. The largest gender pay gap in the EU, both horizontal and vertical segregation in education and the labour market, and men's considerably lower life expectancy are just a few of the issues that mark the state of gender equality in Estonia.

Education is often considered to be one of the key institutions that should be addressed in order to promote equal opportunities and mainstream gender equality. On the one hand, education and schools as institutions do not operate in a vacuum and are informed by the general tendencies, values and attitudes that are prevalent in the society. At the same time, education is a powerful tool for changing the societal attitudes and empowering the next generation. Therefore, it is important to mainstream gender equality in the curricula, school culture, teaching materials and methods in order to prevent the reproduction of gender stereotypes that influence the well-being and choices of pupils. Successful mainstreaming of gender equality, therefore, cannot be achieved without giving (future) teachers the necessary knowledge, tools and teaching methods to understand and tackle gender stereotypes and mainstream gender equality.

This study seeks answers to the following research questions: 1) How do university students perceive gender equality in the society? 2) What is the level of gender awareness among students based on the example of

1 Praxis Centre for Policy Studies, Tornimäe 5, 10145 Tallinn, Estonia; eve.magi@praxis.ee 
labour market behaviour? 3) What are the expectations and attitudes of the students in terms of treating the issue of gender equality during their specialisation studies?

\section{Methodology}

The study reported in this paper uses a mixed methods design. A mixed methods approach is particularly appropriate for this analysis, given the complexity of gender awareness dynamics and attitudes towards gender equality which are addressed in our research questions. The rationale for mixing both quantitative and qualitative data within one study is grounded in the fact that neither approach is sufficient, by themselves, to capture the dynamics and nuances of a situation (Creswell, 2005; Creswell et al., 2003; Ivankova et al., 2006). We use both quantitative analysis of survey data and qualitative analysis of focus group interview data as complementing methods which allow for a more robust analysis and nuanced context by taking advantage of the strengths of each (Creswell et al., 2003; Ivankova et al., 2006).

The final sampling frame for the survey was 2,748 students from all the higher education institutions in Estonia, excluding doctoral students. The survey data was collected electronically with the aim to explore students' awareness, attitudes and experiences of gender equality. The sample for focus group interviews included teacher training students from one university and consisted of 20 individuals. Four semi-structured interviews were conducted using open-ended questions to explore the participants' learning experience in university and attitudes related to gender equality.

The survey data were analysed by using various statistical methods, such as chi-square test for independence, comparison of group means (t-test, analysis of variance), and correlation analysis for investigating relations among variables. The focus group interview data were analysed using qualitative inductive content analysis. The inductive approach was chosen in order to capture clear expressions as well as hidden messages and interpretations related to the research topic (Laherand, 2008). This process included open coding, creating categories and abstraction (Elo \& Kyngäs, 2008). The coding process was undertaken using a software package for Qualitative Content Analysis (QCAmap).

The results are presented according to research questions and illustrated by quantitative and qualitative data. 


\section{Main results and discussion}

Our findings suggest that students perceive that men have a slightly better position than women in the Estonian society. Only 17\% of the teacher training students perceive the situation of men and women as equal. The focus group interviews conducted in this study cast light on potential reasons why students perceive the position of men and women as unequal. The students brought out the fixity of gender roles and self-reinforcing gender stereotypes at home and school. The subjects stressed the desirability of the family model based on gender equality, where both of the parents contribute equally to the functioning of the family.

Our results are in line with previous studies. While most Estonians perceive that men have a better position than women (Vainu et al., 2010), it is interesting that Estonians do not consider gender inequality an important problem. The divide between reality and perception with the problem of gender gap is apparent. The ability to recognise gender stratification is discouraged by gender stereotypes that are evident in the society. The key element here is low awareness of the importance and consequences of gender equality, deeply rooted predispositions and attitudes towards gender equality as well as a low level of competence to recognise and address gender inequality.

The results of our study provide new insights by demonstrating what are the expectations and attitudes of students in terms of treating the issue of gender equality in university studies.

The results indicate that the expectations of the teacher training students concerning the teaching of gender topics in university are high. Interestingly, significant differences exist between students in teacher education and other subjects. Teacher training students concluded that the awareness of gender issues is more likely necessary for their profession and these topics should be integrated into course assignments and Bachelor or Master theses.

Despite the relatively high expectations, the students reported just a couple of courses in which these issues are discussed. Thus, it is not surprising that students' and teacher trainees' level of awareness on gender equality and labour market behaviour is relatively shallow. While most of the students are aware that there is a Gender Equality Act, a quarter of them are unaware of such a law. This result confirms that gender equality has not been an important topic in general education or teacher training. At the same time, the teacher holds one of the key positions to break the norm and gender stereotypes (Fine-Davis \& Faas, 2014). If current teacher 
trainee students and future teachers have random awareness of the topic, then the change towards a generation with a deeper knowledge on gender equality and less stereotypical attitudes is unlikely to appear.

Another interesting finding is that more than a quarter of students are not able to provide evaluations about the degree of awareness of the gender issues of their professors. This indicates that one possibility of better integrating the gender equality topics might be to encourage activities that challenge teacher educators in their pedagogical work to move towards more gender equality in teacher education (Kreitz-Sandberg, 2013).

The gender topic still holds a marginal position in Estonian teacher education (Sugu ja soolisus ..., 2015). If teachers are to play a positive educational role in addressing gender issues influencing social justice and inclusiveness, teacher education institutions will need to ensure that their graduates are well equipped with the attitudes, motivation and skills to enact this role (Cushman, 2012). There are a variety of interlinked difficulties in integrating a gender perspective into teachers education, for example misconceptions around gender, the myth of having already achieved gender equality, a packed curriculum and course planning (Kreitz-Sandberg, 2013; Lahelma, 2014).

Students in our study expressed high demands for attractiveness of course content as well as competent teaching staff in the courses that address the topic of gender equality. Teaching methods that treat the student as an active participant such as group work, discussions, case study analysis, were considered appropriate and engaging methods. Research (Hedlin \& Åberg, 2012; hooks, 2010) reveals that the lecture method is not suitable for teaching topics related to gender and equality, but effective study outcomes are achieved by dialogue with students, while enabling them sufficient time for reflection and analysis of various ideas. Teaching staff in university teacher training programmes can emphasise the importance of gender equality by challenging their values and helping them to recognise their stereotypes through critical pedagogy, social and juridical dimensions (hooks, 2010). For a successful study process, it is important to consider both students' and university teachers' perspective on gender equality and inclusion of gender education in the teacher training curriculum. Hence, we have identified a clear need for exploring university teachers' reflections on gender policies, their perceived role and stereotypes related to gender equality.

Keywords: gender equality, gender mainstreaming in teacher education, attitudes, gender awareness, teacher training, teaching in university 